\title{
Are Financial Development and Corruption Control Substitutes in Promoting Growth?
}

\author{
by
}

Christian Ahlin and Jiaren Pang

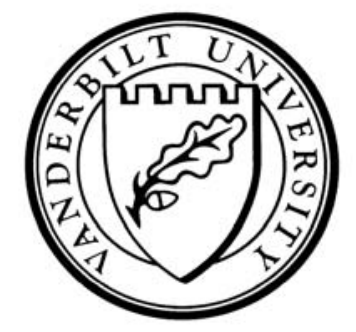

Working Paper No. 07-W09

May 2007

\section{DEPARTMENT OF ECONOMICS \\ VANDERBILT UNIVERSITY \\ NASHVILLE, TN 37235}

www.vanderbilt.edu/econ 


\title{
Are Financial Development and Corruption Control Substitutes in Promoting Growth?
}

\author{
Christian Ahlin and Jiaren Pang* \\ revision December 20, 2006 \\ Keywords: Financial Development; Growth \\ Complementarity; Corruption
}

\begin{abstract}
While financial development and corruption control have been studied extensively, their interaction has not. We develop a simple model in which low corruption and financial development both facilitate the undertaking of productive projects, but act as substitutes in doing so. The substitutability arises because corruption raises the need for liquidity and thus makes financial improvements more potent; conversely, financial underdevelopment makes increased corruption more onerous and thus raises the gains from reducing it. We test this substitutability by predicting growth, of countries and industries, using measures of financial development, lack of corruption, and a key interaction term. Both approaches point to positive effects from improving either factor, as well as to a substitutability between them. The growth gain associated with moving from the 25 th to the 75 th percentile in one factor is $0.63-1.68$ percentage points higher if the second factor is at the 25 th percentile rather than the 75 th. The results show robustness to different measures of corruption and financial development and do not appear to be driven by outliers, omitted variables, or other theories of growth and convergence.
\end{abstract}

${ }^{*}$ Department of Economics, Vanderbilt University and Department of Economics, Washington University in Saint Louis, respectively. We are grateful to Stijn Claessens and Luc Laeven for sharing their data and to three anonymous referees, Pinaki Bose, Hyeok Jeong, Joe Kaboski, Lant Pritchett (the editor), Moto Shintani, Kenichi Ueda, and seminar participants at University of Memphis, University of Southern California, Vanderbilt, and at 75 Years of Development Conference 2004 for helpful comments. Email: c.ahlin@vanderbilt.edu,jpang@wustl.edu. 


\section{Introduction}

The importance, or unimportance, of complementarities has been a recurrent theme in economic development. This issue has been debated in various forms for decades, including by critics and proponents of "Big Push" theory. ${ }^{1}$ Complementarities are important to understand from a positive and normative point of view. Their existence can lead to multiple equilibria and poverty traps, ideas which may be useful in understanding underdevelopment. They also tend to argue for policies characterized by multi-pronged, simultaneous investments rather than piecemeal efforts. For example, if health clinics and clean water are complementary in producing health, it may not be rational to invest in either unless both can be provided; conversely, if they are substitutes, investing in only one of them (at least initially) may well be justified.

The goal of this paper is to focus this interaction question on two key ingredients of development: corruption control and financial development. Recent research (cited below) suggests both factors are important determinants of economic growth. The question we ask is, do they serve as complements or substitutes in promoting growth?

The question of interaction has important implications in this context. Consider a proposal to condition aid on a low level of corruption. One justification could be that low corruption and other development ingredients are complementary - e.g., if corruption is high, improving the financial system will make little difference for growth. This is essentially the point that Johnson et al. (2002) make in the context of several transition economies. But, if corruption control and financial development are substitutes rather than complements, then financial system improvements of the more corrupt countries pay the highest growth dividends. Aid targeted toward financial systems could then best be spent on corrupt countries. $^{2}$ Optimal conditionality depends in part on the sign of the interaction between

\footnotetext{
${ }^{1}$ Participants in this debate include Rosenstein-Rodan (1943), Nurkse (1953), Hirschman (1958), Murphy et al. (1989), Kremer (1993), and, more recently, Sachs (2005) and Easterly (2006).

${ }^{2}$ Of course, if low corruption is not only substitutable with financial development in producing growth, but also complementary to aid in producing financial development, it might still be optimal to condition aid on low corruption.
} 
different instrumental dimensions of development.

Consider further the question of where and how to invest development funds. Under substitutability, it is in the countries at the lowest starting points that a given (moderate) improvement will pay the greatest growth dividend; under complementarity, by contrast, minimal growth dividends result from a given (moderate) improvement in the most backward countries (the thrust of the "Big Push" theory). This is because under substitutability, the greatest gains come from investments early on the development path, while under complementarity, the greatest gains come toward the end of the development path.

Substitutability would also tend to lead to more specialization, i.e. focused improvements along one dimension or another depending on relative costs, while complementarity would argue for comparatively balanced investments. Finally, complementarity would tend to rationalize an all-or-nothing approach - substantially fix both corruption and financial frictions, or do little, depending on relevant costs - while substitutability would tend to rationalize moderate levels of investment that do not vary as widely with costs of improvements. In short, as has long been argued, understanding interactions between different ingredients of development is critical to rational investment in development.

We begin with simple theory to provide a basis for our empirical tests. An economy is endowed with a heterogeneous set of investment projects. These projects can be thought of as representing pure capital accumulation, or as direct investments in research or funding of new firms or ventures that represent economy-wide productivity gains. In this sense, the model is not intended to take a stand on the sources of growth. Each project requires an upfront capital investment that must be borrowed within a potentially inefficient financial system. The inefficiency, i.e. financial underdevelopment, is parameterized as a resource cost of intermediation. Undertaking an investment project also requires a corrupt payment or bribe. Corruption is parameterized as the size of the bribe due, as a fraction of the investment. Thus the focus is on corruption that is costly to the firm, e.g. extortion or payment for services that should be provided for free, rather than on grand corruption or on 
corruption that is beneficial to the firm but costly to society, e.g. collusion with the official to circumvent rational regulation. While all kinds of corruption exist, ample evidence supports this focus. ${ }^{3}$

The model predicts that lower corruption and higher financial development raise investment. Thus the two factors have positive effects taken separately. Under a plausible condition, the two factors act as substitutes in facilitating investment. Substitutability arises because higher corruption raises the need for liquidity and thus makes financial improvements more productive. Conversely, a financially developed country is hurt less by a given increase in corruption, since funds can be borrowed more readily. This result is robust to several alternative assumptions, including the assumption that borrowed money cannot be used to pay bribes.

We test this substitutability empirically, but without providing direct evidence on our theorized mechanism behind substitutability. Hence, we cannot rule out that another theory may also explain the result. There is, however, a bit of corroborative evidence for the mechanism highlighted here in Safavian (2001), who reports on survey data from small businesses in Russia. He finds that enterprises that report being more harried by corruption also apply more often for external finance and rank lack of finance as a greater obstacle to business - this is consistent with the idea that corruption raises the need for external finance. ${ }^{4}$

\footnotetext{
${ }^{3}$ In the survey of 3600 entrepreneurs worldwide summarized by Brunetti et al. (1997), respondents ranked corruption as the second most significant impediment to doing business, ahead of lack of financing. Other similar surveys rank it as a significant obstacle, though not always ahead of financing (see e.g. Beck et al., 2005). Fisman and Svensson (2002), Johnson et al. (2002), Hellman et al. (2003), and Beck et al. (2005) all find evidence that corruption hinders firm growth and/or investment; quantitatively, Johnson et al. find that firms facing pervasive corruption (no corruption) are predicted to have a $33.5 \%$ reinvestment rate (55.1\% reinvestment rate). On a cross-country level, Mauro (1995) finds that corruption hinders investment; quantitatively, a one standard deviation reduction in corruption would raise the investment rate by about five percentage points. Other evidence for corruption that acts as a hindrance, rather than "grease", to entrepreneurs can be found in de Soto (1989), Frye and Shleifer (1997), Berkowitz and Li (2000), Safavian (2001), and Svensson (2003).

${ }^{4}$ Of course, it does not constitute proof. Another possibility is that firms in need of finance also report corruption more because corruption is more strongly concentrated in the financial sector. However, given Safavian's definition of corruption as primarily government-related, and given the minimal government presence in supplying finance in his context, this interpretation seems less likely.
} 
Empirically, we use several standard empirical specifications and datasets that allow for predicting growth, of countries or industries within countries. Explanatory variables include both financial development and corruption indicators. The main measure of financial development is credit issued to private enterprises from commercial banks and other financial institutions, normalized by GDP. Corruption is measured by country-level measures, one compiled monthly as part of the International Country Risk Guide, the other a compilation of surveys by Transparency International. ${ }^{5}$ Our focus is on the term interacting corruption and financial development multiplicatively.

Results confirm the positive effects of financial development and low corruption, respectively, on growth. The interaction term coefficient is itself significant across a variety of specifications and suggests that financial development and low corruption are substitutes in promoting growth. That is, the growth impact of reducing corruption is higher when the financial system is less developed. Conversely, the growth impact of improving the financial system is higher when corruption is high. The estimated magnitude of this interactive effect is large. The growth gain associated with moving from the 25th to the 75 th percentile in one factor is $0.63-1.68$ percentage points higher if the second factor is at the 25 th percentile rather than the 75 th.

The specifications include country-level growth regressions, both cross-sectional and timeseries. We also run industry-level growth regressions following the methodology of Rajan and Zingales (1998), which allows for the inclusion of country and industry fixed effects. Specifically, the country-specific financial development indicator is interacted with an industryspecific measure of dependence on external finance. We extend this approach to corruption. Based on the assumption that bribes charged are proportional to the size of investment undertaken, we interact the country-specific measure of corruption with an industry-specific measure of investment intensity.

This specification performs well, suggesting that corruption's effect on an industry is

\footnotetext{
${ }^{5}$ Data compiled by Kaufmann et al. (2006) are considered by many to be of higher quality, but are only available since 1996; we use these in robustness tests.
} 
mediated by the size of investments required in that industry. The results also consistently confirm Mauro's (1995) finding that corruption hinders growth, but for the first time (to our knowledge) in a setting where country fixed effects are controlled for. ${ }^{6}$ This adds to the case for a causal impact of corruption on growth.

For robustness we exclude outliers and use several other measures for financial development. This includes a measure of stock market activity as well as a less common measure, the spread between the borrowing and saving interest rate, which more closely parallels our model. Finally, we experiment with robustness to non-linearities in the effects of financial development and corruption on growth (as in Rioja and Valev, 2004, and Ahlin, 2005) and to the convergence effects of corruption and financial development (as in Keefer and Knack, 1997, and Aghion et al., 2005). There is substantional robustness across these specifications, leading us to interpret the overall results as strongly suggestive that these two factors are substitutes: improving along one dimension is more valuable (for growth) the less progress has been made in the other dimension.

Most of the existing related literature identifies links between economic outcomes and one or the other of these factors. For example, a large literature has shed light on theoretical and empirical linkages between growth and a well-functioning financial system. ${ }^{7}$ A parallel literature has established significant negative effects of corruption on growth and development, theoretically and empirically. ${ }^{8}$

There are two strands of the literature that examine finance and corruption together, as

\footnotetext{
${ }^{6}$ Svensson (2005) runs a panel specification with country fixed effects and corruption measured by ICRG, and finds no significant relationship. Claessens and Laeven (2003) run a specification similar to ours with country fixed effects and a composite measure of institutional quality from ICRG (including corruption, bureaucratic quality, rule of law, etc.) interacted with intangible property dependence, and find a positive effect.

${ }^{7}$ See, for example, Greenwood and Jovanovic (1990), Bencivenga and Smith (1991), and Aghion et al. (2005) on theoretical links and King and Levine (1993), Rajan and Zingales (1998), Rousseau and Wachtel (1998), Levine et al. (2000), and Aghion et al. (2005) for empirical evidence. Levine (1997, 2005) provides extensive literature reviews.

${ }^{8}$ Cross-country empirical examples include Mauro (1995) and Li et al. (2000), though robustness can be questioned (as in Svensson, 2005); firm-level empirical examples can be found in Fisman and Svensson (2002), Johnson et al. (2002), Hellman et al. (2003), and Beck et al. (2005). Theoretical contributions include Shleifer and Vishny (1993), Ehrlich and Lui (1999), and Ahlin (2005). Bardhan (1997) reviews the literature.
} 
we do. First, a growing field initiated by La Porta et al. (1997, 1998) examines legal origin, and legal and corruption variables more generally, as determinants of financial development. ${ }^{9}$ The focus of this literature tends to be on financial development as the key driver of growth, and low corruption and a functioning legal environment as key ingredients of financial development. We differ from this literature in casting corruption and finance as two factors behind growth that, while related to some degree, may exert independent influence on a country's growth prospects. That is, we feature an effect of corruption on growth that goes above and beyond its effect on the financial system. ${ }^{10}$

The second strand of the literature is smaller and more closely related to our paper in that it examines finance and corruption side by side, allowing for each affect growth independently. Claessens and Laeven (2003) predict industry growth based on financial development and property rights protection. They find that both matter, with property rights protection at least as important quantitatively. Johnson et al. (2002) use firm-level data from five East European transition economies and find that firms that face higher corruption reinvest profits at a significantly lower rate, while access to finance does not seem to affect re-investment. Beck et al. (2005) focus on the interaction between firm size and law, finance, and corruption in predicting firm growth. When law, finance, and corruption are entered into the same regression, corruption is insignificant while finance remains significant (though this is not explicitly interpreted as indicating the greater importance of finance). ${ }^{11}$ No single consensus emerges as to the relative importance of finance and corruption for growth, though

\footnotetext{
${ }^{9}$ Beck and Levine (2004) provide a review of this literature. Among more recent contributions, Chinn and Ito (2005) find that corruption affects the emergence of equity markets; Qian and Strahan (2005) show how corruption and legal variables affect loan contract terms, including use of collateral and maturity; Beck et al. (forthcoming) examine prevalence of corruption in bank lending and its determinants, including the country's overall corruption level; and Khwaja and Mian (2005) show that government banks in Pakistan make cheap, default-prone loans to politically connected firms. A common theme is that corruption can affect and impede efficient operation of the financial system; see also Akerlof and Romer (1993). Bordo and Rousseau (2006), however, show some limits of legal origin in explaining financial development.

${ }^{10}$ See the end of section 2 for a discussion of how the interrelatedness of corruption and finance affects our approach.

${ }^{11}$ This and other work have also compared the two factors based directly on entrepreneurs' ranking of various obstacles to doing business. Beck et al. (2005) and Pissarides et al. (2003) find financing constraints somewhat more prevalent than corruption ones, while Brunetti et al. (1997) find corruption ranked ahead of financial constraints.
} 
the results of Johnson et al. (2002) do suggest the answer is context-specific. To the extent that they examine corruption and finance simultaneously, however, these papers do so via "horseraces"; none directly examines the interaction between them, as we do here.

Our findings suggest there is no need for a coordinated effort (i.e. "Big Push") to develop the financial system and lower corruption simultaneously. This is not to say it would not raise growth to improve along both dimensions. It also does not say that the two factors do not share key ingredients in common. The point is that the greatest growth gains appear to come from taking the first step, in either direction.

In section 2 we outline the model, present the result, and discuss robustness. Sections 3 and 4 describe the data, empirical strategy, and results from, respectively, country-level and industry-level analysis. Section 5 discusses robustness checks. Section 6 concludes.

\section{Theory}

How do financial development and lack of corruption interact in promoting growth? Our aim here is to illustrate a simple interaction mechanism without the full complexity of a growth model. We derive the rate at which new, productive projects are undertaken in a static framework, and show how it varies with both corruption and financial development.

The investment in new productive projects that we model is not intended to implicate one source of growth over another. One alternative is to view the investment as promoting capital accumulation. In this case, the growth promoted by higher investment rates would be able to create temporary growth effects, but perhaps not permanent ones, as diminishing returns to capital set in. A second alternative is to view the projects as providing productivity (TFP) growth. For example, one can interpret the projects as explicit research and development endeavors. More generally, they can be seen as new business ventures that bring fresh ideas into operation and are critical to the Schumpeterian process of creative destruction. ${ }^{12}$ In

\footnotetext{
${ }^{12}$ It is standard to view capital-accumulation growth as dependent on financing. Growth due to investment in new technology has also been seen as dependent on the financial sector. For example, two of the
} 
these cases, higher investment rates could lead to permanently higher growth rates. We view both alternatives as complementary and compatible with the model.

Consider a small open economy endowed with a set of investment projects indexed by $i$. Project $i$ yields present value payoff of $Y_{i}$ at the end of the period. Project payoffs are distributed according to $F\left(Y_{i}\right)$ over support $[0, \bar{Y}]$. All projects require an up-front capital investment of $J$ at the beginning of the period. Capital fully depreciates by the end of the period.

Assume that all projects must be externally financed. ${ }^{13}$ Thus the investment $J$ must be borrowed at the beginning of the period and repaid at the end of the period. Entrepreneurs cannot borrow directly from abroad, but the financial sector can borrow and save at world (gross) interest rate $R$. It then incurs real costs in channeling these resources to local entrepreneurs. Specifically, for every unit of capital reaching the entrepreneur, $\phi \geq 0$ units of capital are used up in intermediation. The parameter $\phi$ is then a measure of financial sector (in)efficiency. In a competitive financial sector the local borrowing interest rate must be $(1+\phi) R$. In this case $\phi$ equals the spread between the saving and lending interest rate, one measure of financial development we use in the empirical work.

Corruption also may exist in the economy. Bureaucrats who hold implicit veto power over businesses' investment projects demand a bribe. The power may be explicitly related to official approval required for investment projects. Even without this, bureaucrats may have some discretionary authority over other areas of the firm's activity, and use the observation of an investment project as a signal of the firm's ability to pay a bribe. We express the bribe as a fraction $\kappa \geq 0$ of $J ;^{14}$ the parameter $\kappa$ measures corruption. ${ }^{15}$

most financially dependent industries in the data of Rajan and Zingales (1998) are the computer and drug industries, both heavily engaged in R\&D. Also, see the growth model of Aghion et al. (2005), in which financial development facilitates technological diffusion.

${ }^{13}$ Section 2.2 discusses several relaxations of this assumption.

${ }^{14}$ Safavian (2001) and Svensson (2003) find evidence that bureaucrats tailor bribes to firm's ability to pay. It seems reasonable to assume that $Y_{i}$ is not observable while $J$ is, so bribe demands are proportional to $J$.

${ }^{15}$ One could endogenize $\kappa$ to maximize bribe revenue from the investment projects. However, this assumes the bureaucrats act as a single monopolist. A degree of competition between them could lower $\kappa$, in the limit to zero. Conversely, a degree of overlapping monopoly power, e.g. where investments require one permit from each of several agencies, could raise $\kappa$, in the limit to exclude nearly all projects as the 'commons' 
The bribe is due 'upfront', at the beginning of the period. This assumption critically implies that corruption raises financing needs. Other assumptions would have the same effect. If the bribe was due not at the beginning but sometime during the implementation phase of the investment project, this would also clearly raise financing needs. Even if bureaucrats came to collect the bribe after project completion, but at some uncertain date, it would raise the firm's need for liquidity. The firm would be forced to hold more liquid assets to be ready to meet demand for bribes; they would thus need more external finance to fund any future investment. Unlike taxes that can be planned for, corrupt demands with uncertain timing result in an ongoing, heightened need for liquidity in a firm; Safavian (2001) provides evidence that the timing of bribe demands is highly uncertain and that firms facing them report higher need for credit. In short, under a number of plausible assumptions, corruption raises financing needs.

\subsection{Investment Effects of Corruption and Finance}

Project $i$ requires $J$ in funds, at end-of-period cost of $(1+\phi) R \cdot J$. It also requires upfront payment of a bribe $\kappa J$, resulting in a loan coming due in the amount of $(1+\phi) R \cdot \kappa J$. The net present value of project $i$ works out to be $Y_{i}-(1+\phi)(1+\kappa) R J$. Thus the financial intermediation resource cost $\phi$ is paid on the capital itself as well as the bribe.

Investment projects with net present value greater than zero satisfy

$$
Y_{i} \geq Y^{*} \equiv(1+\kappa)(1+\phi) R J
$$

In the absence of corruption and financial intermediation costs, this cutoff equals $R J$, which is the end-of-period cost of the used-up capital $J$. Higher corruption and less efficient inter-

is trampled. Varying political organization, then, would produce variation in $\kappa$. For related analysis, see Shleifer and Vishny (1993) and Ahlin (2005). 
mediation set the cutoff for profitable projects higher:

$$
\frac{\partial Y^{*}}{\partial \phi}=(1+\kappa) R J>0, \quad \frac{\partial Y^{*}}{\partial \kappa}=(1+\phi) R J>0 .
$$

There is a non-zero interactive effect on the cutoff:

$$
\frac{\partial^{2} Y^{*}}{\partial \phi \partial \kappa}=R J>0
$$

Higher corruption raises the total financing needs $(J+\kappa J)$ and thus makes an increase in financial overhead more prohibitive. Conversely, a rise in corruption is more prohibitive in a less developed financial system, since corrupt fees raise borrowing needs.

The main goal is to determine how the number of projects invested in, call it $N_{I}$, changes with corruption and financial development. Note that $N_{I}$ equals $1-F\left(Y^{*}\right)$. Not surprisingly, $N_{I}$ is lower the higher is $\phi$ or $\kappa$ :

$$
\frac{\partial N_{I}}{\partial \phi}=-f\left(Y^{*}\right) \frac{\partial Y^{*}}{\partial \phi}=-f\left(Y^{*}\right)(1+\kappa) R J<0
$$

where $f(\cdot)$ is the probability density function, and

$$
\frac{\partial N_{I}}{\partial \kappa}=-f\left(Y^{*}\right) \frac{\partial Y^{*}}{\partial \kappa}=-f\left(Y^{*}\right)(1+\phi) R J<0 .
$$

Higher intermediation costs and higher corrupt fees keep otherwise profitable investments from being made. The interactive effect is given by

$$
\frac{\partial^{2} N_{I}}{\partial \phi \partial \kappa}=-f^{\prime}\left(Y^{*}\right) \frac{\partial Y^{*}}{\partial \phi} \frac{\partial Y^{*}}{\partial \kappa}-f\left(Y^{*}\right) \frac{\partial^{2} Y^{*}}{\partial \phi \partial \kappa}=-f\left(Y^{*}\right) R J\left[\frac{f^{\prime}\left(Y^{*}\right) Y^{*}}{f\left(Y^{*}\right)}+1\right]
$$

where the second equality uses equations 1-3. The effect is negative as long as the elasticity of the density function is greater than negative one at $Y^{*}$. In summary:

Proposition 1. Lower corruption and higher financial development raise the amount of 
investment, $N_{I}$. If $\frac{f^{\prime}\left(Y^{*}\right) Y^{*}}{f\left(Y^{*}\right)}>-1$, the two factors are substitutes in promoting investment.

As can be seen in equation 6 , there are two potentially opposing effects that make up the interaction between the two factors. The first one depends on the slope (elasticity) of the density function. If projects are distributed uniformly, for example, it is zero. If $f^{\prime}\left(Y^{*}\right)<0$, i.e. better projects are rarer among profitable ones, then this effect leads to complementarity: the better one factor is, the greater effect on investment improvements in the other factor have. In a more financially developed country, the project cutoff is of lower value and thus there are more projects on the margin that will be drawn in if corruption is reduced. That is, $Y^{*}$ is lower and thus $f\left(Y^{*}\right)$ is higher. Conversely, in a more corrupt country, fewer projects are on the margin, so improving financial intermediation has less of an impact.

The second effect works toward substitutability regardless of the distribution of project values. The intuition behind this effect is as follows. A reduction in corrupt fees has more of an effect in a financially underdeveloped economy, since they are more burdensome there. Conversely, a reduction in financial intermediation costs has a greater impact in a more corrupt economy, since liquidity needs are higher there.

The net effect then depends on the shape of the project distribution. In particular, substitutability holds as long as the elasticity of project density is not too negative.

\subsection{Extensions and Robustness}

This model gives some basic intuition regarding the interaction between corruption and finance. Here we address its robustness.

The requirement that all projects be externally funded can be relaxed without changing the qualitative results. Similarly, the assumption of uniform project size $J$ can be relaxed. In particular, let there be $M$ industries, indexed by $m$, with a potentially different investment size $J_{m}$ per industry. Further, assume that a fraction $\omega_{m}$ of projects in industry $m$ needs external financing, and that the need for external financing is independent of value $Y_{i}$. Changes in corruption $\kappa$ affect all projects in this scenario, while changes in financial 
(under)development $\phi$ affect only $\omega_{m}$ of the projects. Carrying out the above analysis reveals that the interactive term is exactly the same as derived above (equation 6), except multiplied by $\omega_{m}$ and with the requisite $m$ subscripts:

$$
\frac{\partial^{2} N_{I, m}}{\partial \phi \partial \kappa}=-\omega_{m} f_{m}\left(Y_{m}^{*}\right) R J_{m}\left[\frac{f_{m}^{\prime}\left(Y_{m}^{*}\right) Y_{m}^{*}}{f_{m}\left(Y_{m}^{*}\right)}+1\right] .
$$

Proposition 1 holds with modification to allow for industry-level heterogeneity. In line with this, we control for industry heterogeneity in investment intensity $\left(J_{m}\right)$ and dependence on external finance $\left(\omega_{m}\right)$ in our industry-level empirical specifications discussed below.

A related concern is that the model allows bank financing of bribes. In defense of this assumption, it may often be the case that lenders do not have full control over or knowledge of their clients' use of funds. Loans may be made based on expense estimates rather than actual figures, leaving some discretion to the borrower. Nonetheless, consider the case where firms have enough internal funds to cover bribe demands but not enough to fund the investment $J$ in addition. The substitutability result holds in this setting, even under the assumption that banks will not lend to fund bribery, as we show in Appendix A. The intuition is essentially the same as in the baseline model: higher corrupt fees use up scarce internal funds and thus raise firms' external financing needs.

It might be argued that if bureaucrats tailor bribes to firms' ability to pay, then corruption's effect does not vary with financial development. This is indeed the case under perfect price discrimination, i.e. if bureaucrats extract all the surplus of every project and do not demand more. Then, corruption would not eliminate any socially desirable projects and would thus have no (efficiency) impact regardless of the level of financial barriers. However, if price discrimination is imperfect, ${ }^{16}$ as we model it, then differences in the level of corruption due to factors other than financial development are possible (see footnote 15). As corruption varies in this exogenous way, a marginal increase is more onerous in a financially

\footnotetext{
${ }^{16}$ Indeed, the literature cited above (see footnote 14 ) points toward some price discrimination, but comes nowhere near establishing perfect price discrimination.
} 
underdeveloped system, as the previous section shows.

It may seem undesirable to examine corruption and financial development varying independently, as our partial derivative analysis does. Plausibly $\phi$ is a function of $\kappa$, as the resources wasted in intermediation depend on the level of corruption. ${ }^{17}$ It is also likely that $\kappa$ is a function of $\phi$, since the bureaucrats setting $\kappa$ presumably take the prevailing interest rate $(1+\phi) R$ into account. Alternatively, both $\phi$ and $\kappa$ may be functions of the same underlying factor. If a one-to-one relationship between $\phi$ and $\kappa$ results from these considerations, the partial derivatives are indeed irrelevant.

On the other hand, assume that $\phi$ and $\kappa$ each depend on one or more factors on which the other does not. For example, assume we can write $\kappa(\phi, x, y)$ and $\phi(\kappa, x, z)$. Independent variation in $\phi$ and $\kappa$ is then possible, and the partial derivative is meaningful: $\phi$, say, can vary with $\kappa$ held constant, even though $\kappa$ is a function of $\phi$, because other factors $(y)$ can restore $\kappa$ to its original value without affecting $\phi$.

Put differently, we trace out the full investment surface as a function of $\phi$ and $\kappa$, over the domain $\Re_{+}^{2}$. Equilibrium or interdependence may restrict the domain to less than $\Re_{+}^{2}$, ruling out some combinations of $\phi$ and $\kappa$. As long as there are factors that independently affect both $\phi$ and $\kappa$, the permissible domain is a two-dimensional region of $\Re_{+}^{2}$. Over this region, partial derivatives are relevant.

Nevertheless, this perspective points to a limitation of our approach. We examine the interaction between low corruption and financial development in promoting growth. An equally important question that we do not address deals with interactive effects in producing low corruption and financial development. The interaction might be different at this stage. For example, both may depend crucially on the legal environment. That said, there are quite a few reforms that would predominately affect one factor and not the other: general reform of civil service, promoting competition between bureaucrats, and limiting bureaucratic discretion would mostly affect corruption; rationalizing financial regulation and bank supervision,

\footnotetext{
${ }^{17}$ See references in the introduction, footnote 4 , for evidence and causes of corruption in finance, and its effects.
} 
and providing infrastructure (roads) and basic services (electricity) would mostly affect cost of finance. Thus there seem to be clear ways of influencing each dimension independently.

The empirical analysis of the following sections sheds light on this issue. While corruption and financial development are highly correlated, there apparently remains meaningful independent variation in each dimension.

\section{Cross-Country Results}

Our basic empirical strategy is to predict growth, of countries or industries, using financial development indicators and corruption indicators. The focus in each case is on the coefficient of an interaction term between the finance and corruption variables. Summary statistics of the key variables, described in this and following sections, are presented in Table 1.

The first set of results uses countries as observations. The dependent variable is growth, specifically the average annual real GDP per capita growth figures from the World Development Indicators.

Our main measure of financial development is Private_Credit, total credit issued to private enterprises by deposit money banks and other financial institutions, normalized by GDP. This is a standard measure from the related literature; see, for example, Levine et al. (2000) and Aghion et al. (2005). The numerator is calculated as the sum of lines $22 \mathrm{~d}$ and $42 \mathrm{~d}$ of the International Financial Statistics. Real GDP is taken from line 99b. We take this measure from the Beck, Demirguc-Kunt, and Levine (2000) database, using annual numbers from 1960 to 2000. Arguably, Private_Credit captures the efficiency of financial intermediation as well as the quantity, since it excludes central-bank-allocated credit and credit issued to governments and public enterprises.

We use two corruption measures. They are taken from International Country Risk Guide (ICRG) and Transparency International (TI), respectively. The ICRG data are constructed on the basis of a consistent pattern of evaluation using political information and financial 
and economic data from each country. They include monthly observations on many countries from as far back as 1984. The TI measures are occasional rather than regular (until recently). They reflect averages over other corruption surveys, aggregating the information of business people, academics, and risk analysts. We rescale the TI index so that both indices range 0 to 6 , with a higher value meaning lower corruption. Thus for both financial development and corruption, positive coefficients indicate that improving along this dimension promotes growth.

As a preliminary exercise, we plot countries' financial measure Private_Credit against their corruption measure Corruption_ICRG. The results, over two different time spans dictated by availability of Private_Credit and Corruption_ICRG, are pictured in Figures 1 and $2 .{ }^{18}$ Correlations between the two measures are between 0.6 and 0.65 - high, but by no means ruling out independent variation.

We also divide the data into four bins using each variable's median. In Figure 1, this leaves approximately 8 countries in each off-diagonal bin; the comparable number is about 12 in Figure 2. We report the average growth rates of each bin. This turns up prima facie evidence for substitutability. In all cases, growth is higher for countries above the median than countries below the median, in either dimension. Interestingly, more than half the growth gains associated with moving from below-median to above-median in both dimensions are obtained from improving in the first dimension; in $2 / 4$ of the cases, this first improvement is at least twice as fruitful as the second improvement. The effect from moving from the below-median growth average to the above-median growth average in one dimension is always higher if the country is below-median in the other dimension.

We move to growth regressions for more formal evidence. Let $i$ index countries and $g$ be growth rate of GDP per capita, $C$ and $F$ be the corruption and financial development indicators, respectively, and $X$ be a set of other variables that influence growth. We first

\footnotetext{
${ }^{18}$ Recall that a high corruption score signifies low corruption.
} 
run a basic cross-country OLS specification, predicting growth from 1960-2000:

$$
g_{i}=a+b_{1} C_{i}+b_{2} F_{i}+b_{3} C_{i} F_{i}+b_{4} X_{i}+\epsilon_{i}
$$

The baseline set of control variables $X$ is standard and includes log initial average school attainment, taken from the Barro-Lee dataset, and log initial real GDP per capita. The extended set of cross-country controls includes inflation, government spending as a percent of GDP, the population growth rate, and a measure of trade equal to exports plus imports divided by GDP. The corruption, financial development, and control variables are the simple averages within this period (over all the years for which we have data).

Results from OLS and the two alternative measures of corruption, Corruption_ICRG and Corruption_TI, are contained in columns 1 and 4 of Table 2. Panel A (B) results are from regressions that include the baseline (extended) set of controls. All specifications turn up positive and significant coefficients on the financial and corruption variables. Thus improving along either dimension is associated with higher growth. Interestingly, the interaction term coefficients are negative and significant. This is all the more remarkable due to the high correlation between low corruption and high financial development, which leaves less variation from which to estimate the relationship. Low corruption and financial development appear to be substitutes in promoting growth; that is, the marginal impact of improving along one dimension is higher when the other dimension is less advanced.

We also run 2SLS instrumenting Private_Credit with its initial value over this period. ${ }^{19}$ The idea is that growth may draw the financial sector along with it, but its initial size is plausibly exogenous to the following forty years of growth. An alternative specification is to instrument Private_Credit with a set of variables that indicate legal system origin: English, French, German, Scandinavian, and socialist. These data are taken from La Porta et al. (1999). Legal origin is a common instrument for private credit since it has a strong

\footnotetext{
${ }^{19}$ Countries missing Private_Credit values in 1960 are instrumented by their earliest available value up to 1970 , and dropped if no early enough data exist.
} 
effect on creditor and investor rights and can be argued to affect growth only through these channels; see Levine et al. (2000) and Aghion et al. (2005). It is particularly helpful in this study because it isolates variation in Private_Credit due to differences in legally-induced financial efficiency, thereby enabling us more accurately to approximate the efficiency-ofintermediation variable $\phi$ in the theory.

The 2SLS results are reported in columns 2, 3, 5, and 6 of Table 2. Results are quite similar to those of OLS: low corruption and high financial development promote growth, but act as substitutes in doing so.

This substitutability is quantitatively large. A country at the 75th percentile of our data in both corruption and financial development is predicted to have grown 2.52 percentage points faster than a country at the 25 th percentile of these measures. ${ }^{20}$ These growth gains are concentrated in the first improvement. A country moving up from 25 th to 75 th percentile in one factor enjoys 1.68 percentage points higher growth if the other factor is at the 25 th percentile rather than the 75 th. Growth gains still remain for improving the second factor, but the gains are smaller the stronger is the first factor.

We next turn to pooled cross section analysis to add within-country time variation to the cross-country variation. These regressions are essentially the same as the cross-country regressions except that all variables now correspond to a country-decade pair:

$$
g_{i t}=a+b_{1} C_{i}+b_{2} F_{i t}+b_{3} C_{i} F_{i t}+b_{4} X_{i t}+\nu_{t}+\epsilon_{i t}
$$

Thus the dependent variable is growth in a given decade and country. Decade dummies are included. Initial GDP of the decade is used, along with the initial schooling in the decade. The financial variable is a decade-average, with its instrument (when used) being the value

\footnotetext{
${ }^{20}$ This uses the averages of coefficient estimates across Corruption_ICRG and Corruption_TI specifications, respectively, from Table 2; it then averages across the Corruption_ICRG and Corruption_TI results. The 25th percentile for Corruption_ICRG (Corruption_TI) is 2.64 (1.89) and the 75th percentile is 4.68 (4.42). For Private_Credit, the respective numbers are 0.19 and 0.51 .

Oddly, for high values of finance or corruption, the marginal effect of improving the other factor can be negative. We conjecture this is because of non-linearities, but a multi-dimensional nonparametric approach is not feasible given data limitations.
} 
at the beginning of the decade. The one exception in these regressions is that for a given country, the corruption variable is set equal to the simple average across all years regardless of the decade, since the data do not extend back beyond the early 1980s.

Results are reported in Table 3, where again Panel A (B) results are from regressions that use the baseline (extended) set of controls. The results are qualitatively the same as in Table 2, if quantitatively muted.

Next we use data over 1980-2000 with five-year averages to estimate the following equations:

$$
g_{i t}=a+b_{1} C_{i t}+b_{2} F_{i t}+b_{3} C_{i t} F_{i t}+b_{4} X_{i t}+\nu_{t}\left(+\eta_{i}\right)+\epsilon_{i t}
$$

Given that the ICRG time series begins in 1984, this time-horizon allows us to capture corruption varying by time period - thus corruption will be measured only by Corruption_ICRG. It also allows us to use the initial value of corruption as its instrument in a pooled regression. In addition, it is well-known that the cross-country and pooled specifications may produce biased estimates due to the omission of country-specific effects. We can partially address this concern by including the country-specific effect $\eta_{i}$ and using the panel aspect of the data. $^{21}$ Disadvantages in these approaches may arise in that the growth rates are reflecting higher frequency macroeconomic fluctuations, or that independent variables (in particular, corruption) do not vary enough over this relatively short time span.

Specifically, we use the "system GMM" panel techniques proposed by Arellano and Bover (1995) and Blundell and Bond (1998), extending earlier work of Arellano and Bond (1991). ${ }^{22}$ These consistently and efficiently estimate the above parameters under certain assumptions. Critically, realizations of the independent variables must not be correlated with future error terms $\left(\epsilon_{i t^{\prime}}\right.$ for $\left.t^{\prime}>t\right)$. For example, this requires that financial development does not anticipate future innovations to the growth rate. Also, it must be that, while the inde-

\footnotetext{
${ }^{21}$ In the section 4 we use industry-level data to address country-specific effects using techniques of Rajan and Zingales (1998).

${ }^{22}$ For more detail on the required assumptions and instruments used, and a general introduction to application of these techniques, see Bond (2002). Beck et al. (2000) and Levine et al. (2000) also discuss and apply them in a similar setting.
} 
pendent variables are allowed to be correlated with the country fixed effect, changes in the independent variables are not.

Table 4 contains results using the pooled cross sections over 1980-2000 in panel A and results using system GMM estimation in panel B. ${ }^{23}$ The first (last) two columns include the baseline (extended) set of controls.

The results of the pooled regressions are in line with the previous results, with positive and significant coefficients on corruption and finance, and negative and significant coefficients on their interaction. The GMM estimations also give evidence for positive effects from both factors and a substitutability between them. The one exception is that the corruption variable is insignificant in one of the specifications. There is perhaps not enough within-country variation over these decades to estimate a precise relationship. With this partial exception, though, the country-level evidence supports the idea of positive effects of improving both factors, but substitutability between them.

An interesting question to explore is how these two factors are leading to growth: through capital accumulation or productivity growth. Using data constructed by Beck, Levine, and Loayza (2000), we run the baseline specifications of Table 2 but change the dependent variable to average annual physical capital growth in panel A, Table 5, and to average annual productivity growth in panel B, Table $5 .^{24}$ Much the same pattern emerges, with significant positive coefficients on the linear terms and significant negative coefficients on the interaction term in many cases. The results are quite robust for productivity growth (indeed, Beck, Levine, and Loayza find a more robust relationship between financial development and productivity growth), but less so for capital growth when corruption is measured by

\footnotetext{
${ }^{23}$ For the GMM estimation, we use the one-step robust estimator; two-step estimation gives similar results, which are not reported. The results are from the "xtabond2" command in Stata by Roodman (2005). We use lags of one and greater for initial GDP/capita and initial schooling, since they are predetermined, and lags of two or greater for the other independent variables.

${ }^{24}$ Capital growth rates are derived, first by obtaining an initial estimate of the capital stock in 1950 , assuming that each country was at its steady-state capital-output ratio in 1950; and next by using the aggregate real investment series from the Penn-World Tables and the perpetual inventory method with a depreciation rate of seven percent to compute capital stocks in later years. Productivity growth is calculated as a residual, equal to the (growth rate of GDP/capita $-0.3^{*}$ growth rate of physical capital/capita). These data cover 1960-1995, so the independent variables are restricted to this period in Table 5 specifications.
} 
Corruption_ICRG. ${ }^{25}$ This evidence is not inconsistent with our model of investment, where the investment can be in productivity-enhancing projects or in capital.

\section{Industry Results}

We next turn to industry-level growth tests. We use the same dataset as Claessens and Laeven (2003), who augment the original dataset of Rajan and Zingales (1998). There are 38 industries represented from 45 countries. ${ }^{26}$ The United States is dropped because it is used to construct the industry benchmarks (discussed below) for external finance dependence and investment intensity. The dependent variable is the average annual real growth rate of value added for each industry in each country over 1980-1989. As is standard, we use as controls the industry's share of total manufacturing in each country in 1980, and country and industry dummies.

To get an industry-level measure of financial development, we follow the approach of Rajan and Zingales (1998) and interact the country-level financial development indicator with an industry-level measure of financial dependence. This financial dependence measure is intended to capture the degree of reliance on external financing in a given industry in the ideal case, that is, driven only by the technological parameters of an industry (project scale, gestation period, and so on). The financial dependence of a firm equals capital expenditures minus cash flow from operations, divided by capital expenditures; the financial dependence of an industry is that of the median firm in the U.S. industry.

Claessens and Laeven (2003) take the analysis further by including as an explanatory variable a country-level property rights protection indicator interacted with an industryspecific measure of dependence on intangible property. This addresses a somewhat related question to the one here. The major difference is that their focus is on protection of rights to intangible property, such as patents and trademarks. By contrast, we aim to study

\footnotetext{
${ }^{25}$ Results for the extended specifications, i.e. including four additional country controls as described above, are very slightly weaker and are not reported for brevity.

${ }^{26}$ See Claessens and Laeven (2003) for a list. We are left with 36 industries after missing data are dropped.
} 
corruption that acts as a tax on investment in any kind of property, including tangible. Thus we continue to use our corruption measure in these tests.

It would be desirable to find an industry-level variable to proxy dependence on an uncorrupt environment. The natural candidate from theory is the investment intensity (see the $J_{m}$ term in equation 7 ). In general, larger investments make a firm's profitability harder to conceal and easier to exploit due to hold-up. Regulation of investment projects, whether construction permits or the licensing of new products, may also be precisely the door through which bureaucratic discretion enters to extract illegal payments from firms. Conversely, small investments are less likely to be regulated, tracked, and exploited. ${ }^{27}$ Following this line of reasoning, we interact the country-level corruption variable with the industry-level investment intensity. This variable is calculated using U.S. industries as benchmarks in the same way as the financial dependence variable. It captures the ratio of capital expenditures to property, plant, and equipment. ${ }^{28}$ Summary statistics of investment intensity and financial dependence are presented in Table 1.

Let $i$ index countries and $j$ index industries, $D_{j}$ be financial dependence, $I_{j}$ be investment intensity, $g_{i j}$ be the industry growth rate, $S 0_{i j}$ be industry $j$ 's initial share in country $i$ 's manufacturing, and other variables be as defined above. Our baseline specification is

$$
g_{i j}=a+b_{0} S 0_{i j}+b_{1} F_{i} D_{j}+b_{2} C_{i} I_{j}+b_{3} F_{i} D_{j} C_{i} I_{j}+\nu_{j}+\eta_{i}+\epsilon_{i j}
$$

The financial dependence variable ratchets up or down effects of financial development and investment intensity does the same for corruption. Industry and country fixed effects are included. In some specifications, we use the legal origins variables or the initial value of

\footnotetext{
${ }^{27}$ Another rationale for corruption's effect to be proportional to the size of investment could be that larger investments are easier for firm managers to illegally profit from. For example, they could involve more customized rather than standard products, leaving room for kickbacks that would be impossible in a standardized procurement process; this follows Shleifer and Vishny (1993). High-investment industries would then be more corrupt and efficient investment would be would be lower, hindering growth. However, this interpretation revolves mainly around white-collar crime/corruption, rather than corruption in its most common sense and in what the data aim to capture: misuse of public office.

${ }^{28}$ There is high correlation between investment intensity and financial dependence of industries: 0.81 .
} 
Private_Credit as instruments for Private_Credit, as in the country-level regressions.

One advantage of industry-level analysis is that it allows for testing the hypothesis across heterogeneous industries that should have different responses to financial development and corruption. A second key advantage is the ability to control for unobserved heterogeneity across countries.

Table 6 reports results from the baseline industry-level regressions. All specifications turn up strong evidence in favor of the model. Both factors have positive effects separately. The interaction term's coefficient is negative, suggesting the effect of one factor is greater the less advanced is the other factor.

The quantitative interactive effect is smaller than in the cross-country analysis, but still large. Consider an industry with mean financial dependence (0.32) and mean investment intensity (0.30). In a country moving up from the 25 th to the 75 th percentile in one factor, this industry enjoys 0.63 percentage points higher growth if the other factor is at the 25 th percentile rather than the 75 th. $^{29}$

Table 6 offers interesting evidence regarding the effect of corruption. First, it exhibits a strong negative effect on industry growth even when unobserved country heterogeneity is controlled for using country dummies. Previous empirical work on corruption and growth, for example Mauro (1995), has been cross-sectional in nature and thus subject to omitted variable bias. Panel techniques have some promise in solving this problem, but are hindered by lack of variation in corruption over the short time for which data are available. The technique used here confirms the negative effect while controlling for differences across countries. Second, the effect of corruption appears to be mediated by the size of investment needed in a given industry. Evidently, industries with larger required investments are more vulnerable to corruption and thus more dependent on less corrupt institutions.

For robustness purposes, we also interact corruption with the financial dependence variable instead of investment intensity. There are two such specifications, since the interaction

\footnotetext{
${ }^{29}$ This uses the averages of coefficient estimates across Corruption_ICRG and Corruption_TI specifications, respectively, from Table 6; it then averages across the Corruption_ICRG and Corruption_TI results.
} 
term can plausibly be $F_{i} C_{i} D_{j}$ or $F_{i} C_{i} D_{j}^{2}$. The results (not reported) are similar. We also add the Claessens and Laeven (2003) term interacting intangible asset dependence with property rights protection to check whether our results continue to hold. Our key interaction term remains significant and negative in $5 / 6$ of the specifications of Table 6 (not reported), dropping just slightly out of range (p-value: 0.11 ) in the remaining $1 / 6$.

\section{Robustness}

In this section, we check robustness to outliers, different measures of financial development, non-linearities, and convergence effects of financial development.

\subsection{Outliers}

Figure 1 makes clear that the most extreme outliers are countries with very high Private_Credit (Japan and Switzerland); in contrast, no country is very far in corruption level from several other countries. Thus we rerun the baseline cross-country and industry specifications of Tables 2 and 6, excluding countries with Private_Credit $>1$. These results are in Table 7, with non-focal variables not reported. They are slightly weaker in the cross-country specifications (interaction term insignificant in 4/12 specifications) and equally strong in the industry specifications. It does not appear that the substitutability result is being driven by outliers. ${ }^{30}$

We also rerun the baseline specifications of Tables 2 and 6, dropping one country at a time. The maximum and minimum (in absolute value) coefficient estimates and t-statistics for the finance-corruption interaction term are reported in Table 8, along with the baseline estimates and t-statistics. The cross-country results show significant robustness, with only $3 / 12$ of the specifications delivering minimum t-statistics that are below conventional significance levels. The industry results are less strong, with minimum t-statistics not within conventional

\footnotetext{
${ }^{30} \mathrm{We}$ also run quantile (median) regressions for the baseline OLS specifications of Tables 2 and 6 (not reported). The key variables are significant at the same or higher levels.
} 
significance levels. Part of the explanation is likely that there are fewer countries (but multiple industries per country) in the industry regressions.

\subsection{Different corruption and financial measures}

Kaufmann et al. (2006) provide a corruption index that carefully aggregates corruption measures from numerous sources. These data are likely to be of higher quality than ICRG; however, they only extend back to 1996, which is after most of our growth data. As a robustness test, we use this measure averaged over 1996-2000, call it Corruption_KKM, in the baseline cross-country and industry tests. Results are reported in Table 9. The picture is essentially unchanged, though in one industry specification the coefficients on finance and the corruption-finance interaction turn just insignificant.

Our focal endogeneity concern is with financial development, but there may be valid endogeneity concerns with corruption as well, due partly to the measures' subjectivity. For example, it may be that consultants and respondents are more likely to rate a stagnant economy as corrupt. This concern is alleviated to some degree by the industry-level specifications, which identify corruption's effect off of differential responses of industries to corruption based on their typical investment intensity. An instrumental variable approach could also be helpful. One commonly used institutional instrument is the settler mortality variable of Acemoglu et al. (2001). A significant problem in using this is that the intersection of settler mortality with our data cuts sample sizes in about half. Nonetheless, we run the baseline cross-country and industry specifications, also instrumenting corruption with settler mortality (not reported). The cross-country results turn up no significant coefficients at all; the industry results maintain significance only when financial development is instrumented by its initial value. We conclude that due to lack of data, this strategy gains little ground on the corruption endogeneity issue.

The measure of financial development used thus far, Private_Credit, reflects both quantity and quality of financial intermediation. The key variable in the theory, $\phi$, is purely a measure 
of intermediation efficiency. We have addressed this problem to some extent by instrumenting Private_Credit with legal origins. Legal origins can be said mainly to affect the efficiency with which the financial system solves the problems inherent in intermediation. Here we supplement this approach by checking whether other measures of financial development exhibit the same substitutability with corruption.

Our main alternative measure comes from the theory, which suggests using the spread between the borrowing and saving interest rate: this is exactly equal to $\phi$. We calculate this measure by geometrically averaging the real borrowing interest rate over the given time period, subtracting the similarly calculated saving interest rate, and taking logs. This we call Log_Real_Spread. The borrowing and saving interest rates are taken from IFS lines 60P and $60 \mathrm{~L}$, respectively, and become widely available only gradually through the 1980s. Inflation is drawn from IFS line 64. Summary statistics are presented in Table 1. To our knowledge, this measure has not been used in the literature as a proxy for financial development in explaining growth. ${ }^{31}$ We also use the ratios of liquid liabilities to GDP, denoted as LLY, and deposit money bank assets to GDP, denoted as DMBY, other measures that have been used in the literature. These are taken from Beck, Demirguc-Kunt, and Levine (2000). For each of these measures except Log_Real_Spread, a higher number indicates greater financial development.

We run the baseline specifications of Tables 2 and 6 with financial development measured by Log_Real_Spread and a time span of 1985-2000 rather than 1960-2000, due to data availability. Results are reported in Table 10. Cross-country evidence is supportive: $7 / 8$ of the specifications turn up a positive and significant sign on the interaction term, and a negative and significant sign on Log_Real_Spread, as the theory predicts. ${ }^{32}$ Industry-level results are extremely weak, turning up no significant coefficients on Log_Real_Spread or the interaction term. One partial explanation may be the reduced sample size relative to Table 6 .

\footnotetext{
${ }^{31}$ Laeven and Majnoni (2003) use the spread to measure the cost of capital and examine how it is affected by rule of law.

${ }^{32}$ Note that high Log_Real_Spread implies low financial development. We refrain from instrumenting by initial value since the spread is more volatile, it is not a quantity variable, and the time span is shorter.
} 
Overall, the evidence using Log_Real_Spread is only partially supportive. It also suggests that Log_Real_Spread may not be an ideal measure of the cost of liquidity, perhaps because it is volatile and involves the summarizing of the financial system into one borrowing and one saving interest rate.

The specifications of Table 2 are also run with financial development measures LLY and DMBY, respectively, replacing Private_Credit (not reported). Results for DMBY are somewhat supportive of the baseline results, turning up significant and negative coefficients in $7 / 12$ cases. The exceptions are in the IV specifications and always involve both the finance term and the interaction term insignificant. LLY performs worse, ${ }^{33}$ with only $2 / 12$ of the specifications yielding significant and negative coefficients on the interaction term; another 5/12 are 'close' to significant (p-values below 0.2). As with DMBY, the remaining cases are in the IV specifications and involve both the finance and interaction terms as insignificant. In summary, LLY and DMBY do not perform as well as Private_Credit, but do suggest some support for the results obtained using Private_Credit.

Finally, we go beyond bank financing to include measures of stock market activity. Levine and Zervos (1998) find that stock market liquidity, measured as the ratio of the value of total shares traded on the stock market exchange to GDP, positively predict growth. We follow them and use the same measure, taken from Beck, Demirguc-Kunt, and Levine (2000) and denoted here Stock_Traded. Table 11 reproduces the baseline specifications of Tables 2 and 6 using Stock_Traded instead of Private_Credit, and covering the years 1980-2000. ${ }^{34}$ The results are very similar to those obtained using measures of bank finance; in particular, the interaction term is negative and significant in all specifications. We also create a simple aggregate measure of finance, equal to the sum of Private_Credit and Stock_Traded. Results using this aggregate finance measure are reported in Table 12. The results are again strong: the interaction term is negative and significant in 10/12 cross-country specifications and all

\footnotetext{
${ }^{33}$ Others, including Aghion et al. (2005), have found similar poor performance from LLY.

${ }^{34}$ Stock_Traded becomes more widely available in the 1980s and 1990s. We exclude countries with Stock_Traded observations for less than half of the years covered in each regression.
} 
industry specifications. In the $2 / 12$ specifications where it is not significant, the number of observations is small and the coefficients on corruption and finance are also not significant.

Overall, the results show significant robustness to other measures of financial development.

\subsection{Non-linear effects of financial development and corruption}

One might wonder if the substitutability results are due to some kind of non-linearity not accounted for. In particular, recent studies suggest that the effect of financial development on growth exhibits diminishing returns (Rioja and Valev, 2004). If so, the negative coefficient on the interaction term may be in part driven by our linear specification. ${ }^{35}$ Accordingly, we modify our specifications to allow for non-linear effects, adding in turn a finance-squared term and a corruption-squared term. This alleviates concerns that the results are being driven by imposed linearity in the effects of corruption and financial development.

Results from the baseline specifications of Tables 2 and 6 , with the addition of a quadratic financial development term, are reported in Table 13. They cast little doubt on previous findings. The interactive term coefficient remains negative and significant in $6 / 8$ of the crosscountry specifications and all of the industry specifications. ${ }^{36}$ The squared term is typically negative but not significant.

Ahlin (2005) shows a theoretical non-linear relationship between corruption and output. Hence, we repeat the above procedure including a quadratic corruption term instead of a quadratic finance term. ${ }^{37}$ The results are reported in Table 14, and are equally strong. The interactive term coefficient remains negative and significant in 10/12 of the cross-country

\footnotetext{
${ }^{35}$ More specifically, assume the data are generated according to $g=\alpha+\beta_{1} F+\beta_{2} C-\beta_{3} F^{2}+\varepsilon$, where $\beta_{i}>0$. Simple Monte Carlo simulations show that estimating the equation $g=a+b_{1} F+b_{2} C+b_{3} F C+\epsilon$ typically produces negative estimates for $b_{3}$ if $F$ and $C$ are positively correlated, as they are in the data.

${ }^{36}$ Since the legal origins variables are indicator variables, they cannot be used to instrument both finance and finance-squared. This specification is omitted.

${ }^{37}$ We prefer adding one at a time due to the small sample size. However, when both squared terms are added simultaneously, the results are similar. The interactive term is significant and negative in $4 / 8$ of the cross-country specifications and all the industry specifications. The cross-country specifications in which it fails to be significant are all IV; all the focal variables lose significance in all of these, except the linear private credit term in $2 / 4$.
} 
specifications and all of the industry specifications.

Overall, the evidence suggests that the substitutability result is not being driven by non-linear growth effects of corruption or financial development.

\subsection{Convergence effects of corruption and financial development}

Cross-country empirical work has given evidence that both corruption (Knack, 1996, and Keefer and Knack, 1997) and financial development (Aghion et al., 2005) are determinants of income convergence. Consider the latter result; if corruption is strongly correlated with initial income, the interaction term coefficient we estimate may be in danger of reflecting this convergence result rather than the interaction between corruption and finance.

We rerun the baseline cross-country specifications of Table 2, alternately adding in an interaction term between log initial income and financial development (Panel A, Table 15) and an interaction term between log initial income and corruption (Panel B, Table 15). In Panel A, the corruption-finance interaction is significant in $2 / 6$ specifications $(3 / 6$ of the specifications with extended controls, unreported), while the finance-initial_income interaction is significant in none (1/6 of the specifications with extended controls, unreported). In Panel $\mathrm{B}$, the corruption-finance interaction is significant in $4 / 6$ specifications $(4 / 6$ of the specifications with extended controls, unreported), while the finance-initial_income interaction is significant in none (as also in the specifications with extended controls, unreported). We conclude, from the instances in which the specifications are not overloading the small sample size, that the substitutability results of the baseline specifications are not being driven by the convergence effects of corruption or financial development.

\section{Conclusion}

Both financial development and corruption control appear to have positive effects on growth, of industries or countries. Further, these two factors appear to operate as substitutes: when 
one is weaker, the marginal impact from improving the other is greater. This result holds true across a variety of specifications with substantial robustness.

Our proposed rationale for the existence of such an interaction is that corruption raises the need for liquidity and thus makes financial development more potent. Conversely, low financial development adds to the weight of increased corruption and thus increases the gain from reducing it.

The industry-level regressions provide new evidence on the effects of corruption. First, it appears that corruption's effect on a given industry is mediated by the typical size of investment required in that industry. This is evidenced by the strong performance of the industry specifications, in which the country-level corruption measure is interacted with the industry-level investment intensity measure. Second, this methodology allows us to gauge the effect of corruption in regressions with country-level fixed effects included. The evidence confirms earlier cross-country findings: corruption has a negative growth effect.

One additional rationale for considering the interaction we do surfaces in Table 16. It shows results from the baseline specifications of Tables 2 and 6 , excluding the interaction term. The result is that both of these factors appear to be less robust predictors of growth. ${ }^{38}$ Based on the earlier results, this may be due to the omission of a key interaction rather than to a weak relationship.

An interesting question is whether corruption control or financial development has a greater impact on growth. Since measurement error can affect estimates of coefficient magnitudes and since it may exist to different degrees in our measures of corruption and finance, a definitive stance on this question seems unwarranted. However, using the cross-country results of Table 2 and the averaging described in footnote 14, improving financial development first, i.e. from the 25 th percentile to the 75 th percentile with corruption control remaining at the 25th percentile, is associated with 2.34 percentage points more growth. Improving corruption control first is associated with 1.86 percentage points more growth. These point

\footnotetext{
${ }^{38}$ Svensson (2005) points out the non-robustness of corruption as a predictor of growth.
} 
estimates suggest that the financial improvement would come with a $25 \%$ greater boost to growth. However, equality of the respective growth dividends cannot be rejected at standard confidence levels in 9/12 of the Table 2 specifications; of the $3 / 12$ where it can, all involve the Corruption_ICRG measure and only one can reject at the $5 \%$ level. ${ }^{39}$ Of course, costs of such improvements are not taken into account either.

Overall, the results suggest that a "little push", that is, a step in one direction or the other by a developing country (toward better finance or less corruption) can bring substantial rewards. Of course, there is overlap in the institutions and other ingredients behind financial development and corruption control. On the other hand, the fact that an interactive coefficient could often be estimated relatively accurately suggests there is independent variation in progress across these two dimensions. We conclude that these factors may well act as substitutes, which is good news for developing countries.

\section{References}

[1] Daron Acemoglu, Simon Johnson, and James A. Robinson. The colonial origins of comparative development: An empirical investigation. American Economic Review, 91(5):1369-1401, December 2001.

[2] Philippe Aghion, Peter Howitt, and David Mayer-Foulkes. The effect of financial development on convergence: Theory and evidence. Quarterly Journal of Economics, 120(1):173-222, February 2005.

[3] Christian Ahlin. Effects and (in)tractability of decentralized corruption. Mimeo, Vanderbilt University, December 2005.

[4] George A. Akerlof and Paul M. Romer. Looting: The economic underworld of bankruptcy for profit. Brookings Papers on Economic Activity, 0(2):1-60, 1993.

[5] Manuel Arellano and Stephen Bond. Some tests of specification for panel data: Monte carlo evidence and an application to employment equations. Review of Economic Studies, 58:277297, 1991.

[6] Manuel Arellano and Olympia Bover. Another look at the instrumental variable estimation of error-components models. Journal of Econometrics, 68(1):29-52, July 1995.

\footnotetext{
${ }^{39}$ Results from the industry-level estimates of Table 6 favor corruption control as more effective, but the measurement error concern is compounded since the industry-level interaction variables differ across corruption and finance and may also be measured with error. When the same interaction variable is used for both corruption and finance, quantitative impacts are close to equality.
} 
[7] Pranab Bardhan. Corruption and development: A review of issues. Journal of Economic Literature, 35(3):1320-1346, September 1997.

[8] Thorsten Beck, Asli Demirguc-Kunt, and Ross Levine. Bank supervision and corruption in lending. Journal of Monetary Economics, forthcoming.

[9] Thorsten Beck, Asli Demirguc-Kunt, and Ross Levine. A new database on the structure and development of the financial sector. World Bank Economic Review, 14(3):597-605, September 2000 .

[10] Thorsten Beck, Asli Demirguc-Kunt, and Vojislav Maksimovic. Financial and legal constraints to growth: Does firm size matter? Journal of Finance, 60(1):137-177, February 2005.

[11] Thorsten Beck and Ross Levine. Legal institutions and financial development. NBER Working Paper 10417, April 2004.

[12] Thorsten Beck, Ross Levine, and Norman Loayza. Finance and the sources of growth. Journal of Financial Economics, 58:261-300, 2000.

[13] Valerie R. Bencivenga and Bruce D. Smith. Financial intermediation and endogenous growth. Review of Economic Studies, 58(2):195-209, April 1991.

[14] Daniel Berkowitz and Wei Li. Tax rights in transition economies: A tragedy of the commons? Journal of Public Economics, 76(3):369-397, June 2000.

[15] Richard Blundell and Stephen Bond. Initial conditions and moment restrictions in dynamic panel data models. Journal of Econometrics, 87(1):115-143, November 1998.

[16] Stephen Bond. Dynamic panel data models: A guide to micro data methods and practice. Portuguese Economic Journal, 1(2):141-162, August 2002.

[17] Michael D. Bordo and Peter L. Rousseau. Legal-political factors and the historical evolution of the finance-growth link. NBER Working Paper 12035, February 2006.

[18] Aymo Brunetti, Gregory Kisunko, and Beatrice Weder. Institutional obstacles for doing business: Region-by-region results from a worldwide survey of the private sector. World Bank Policy Research Working Paper No. 1759, Washington DC: The World Bank, April 1997.

[19] Menzie D. Chinn and Hiro Ito. What matters for financial development? Capital controls, institutions, and interactions. NBER Working Paper 11370, May 2005.

[20] Stijn Claessens and Luc Laeven. Financial development, property rights, and growth. Journal of Finance, 58(6):2401-2436, December 2003.

[21] Hernando de Soto. The Other Path. Harper and Row, New York, 1989.

[22] William Easterly. The big push deja vu: A review of Jeffrey Sachs's The end of poverty: Economic possibilities for our time. Journal of Economic Literature, 44:96-105, March 2006.

[23] Isaac Ehrlich and Francis T. Lui. Bureaucratic corruption and endogenous economic growth. Journal of Political Economy, 107(6):S270-S293, December 1999.

[24] Raymond Fisman and Jakob Svensson. Are corruption and taxation really harmful to growth? Firm level evidence. Draft, April 2002. 
[25] Timothy Frye and Andrei Shleifer. The invisible hand and the grabbing hand. American Economic Review, 87(2):354-358, May 1997.

[26] Jeremy Greenwood and Boyan Jovanovic. Financial development, growth, and the distribution of income. Journal of Political Economy, 98(5):1076-1107, October 1990.

[27] Joel S. Hellman, Geraint Jones, and Daniel Kaufmann. Seize the state, seize the day: State capture and influence in transition economies. Journal of Comparative Economics, 31:751-773, 2003.

[28] Albert O. Hirschman. The Strategy of Economic Development. Yale University Press, New Haven, 1958.

[29] Simon Johnson, John McMillan, and Christopher Woodruff. Property rights and finance. American Economic Review, 92(5):1335-1356, December 2002.

[30] Daniel Kaufmann, Aart Kraay, and Massimo Mastruzzi. Governance matters V: Aggregate and individual governance indicators for 1996-2005. World Bank Policy Research Working Paper No. 4012, Washington DC: The World Bank, September 2006.

[31] Philip Keefer and Stephen Knack. Why don't poor countries catch up? A cross-national test of an institutional explanation. Economic Inquiry, 35(3):590-602, July 1997.

[32] Asim Ijaz Khwaja and Atif Mian. Do lenders favor politically connected firms? Rent provision in an emerging financial market. Quarterly Journal of Economics, 120(4):1371-1411, November 2005 .

[33] Robert G. King and Ross Levine. Finance and growth: Schumpeter might be right. Quarterly Journal of Economics, 108(3):717-737, August 1993.

[34] Steve Knack. Institutions and the convergence hypothesis: The cross-national evidence. Public Choice, 87(3-4):207-228, June 1996.

[35] Michael Kremer. The O-ring theory of economic development. Quarterly Journal of Economics, 108(3):551-575, August 1993.

[36] Rafael La Porta, Florencio Lopez de Silanes, Andrei Shleifer, and Robert W. Vishny. Legal determinants of external finance. Journal of Finance, 52(3):1131-1150, July 1997.

[37] Rafael La Porta, Florencio Lopez de Silanes, Andrei Shleifer, and Robert W. Vishny. Law and finance. Journal of Political Economy, 106(6):1113-1155, 1998.

[38] Rafael La Porta, Florencio Lopez de Silanes, Andrei Shleifer, and Robert W. Vishny. The quality of government. Journal of Law, Economics, and Organization, 15(1):222-279, April 1999.

[39] Luc Laeven and Giovanni Majnoni. Does judicial efficiency lower the cost of credit? World Bank Policy Research Working Paper No. 3159, Washington DC: The World Bank, October 2003.

[40] Ross Levine. Financial development and economic growth: Views and agenda. Journal of Economic Literature, 35(2):688-726, June 1997. 
[41] Ross Levine. Finance and growth. In P. Aghion and S. N. Durlauf, editors, Handbook of Economic Growth, volume 1A. Elsevier Press, 2005.

[42] Ross Levine, Norman Loayza, and Thorsten Beck. Financial intermediation and growth: Causality and causes. Journal of Monetary Economics, 46(1):31-77, August 2000.

[43] Ross Levine and Sara Zervos. Stock markets, banks, and economic growth. American Economic Review, 88(3):537-558, June 1998.

[44] Hongyi Li, Lixin Colin Xu, and Heng-Fu Zou. Corruption, income distribution, and growth. Economics and Politics, 12(2):155-182, July 2000.

[45] Paolo Mauro. Corruption and growth. Quarterly Journal of Economics, 110(3):681-712, August 1995.

[46] Kevin M. Murphy, Andrei Shleifer, and Robert W. Vishny. Industrialization and the big push. Journal of Political Economy, 97(5):1003-1026, October 1989.

[47] Ragnar Nurkse. Problems of Capital Formation in Underdeveloped Countries. Oxford University Press, New York, 1953.

[48] Francesca Pissarides, Miroslav Singer, and Jan Svejnar. Objectives and constraints of entrepreneurs: Evidence from small and medium size enterprises in Russia and Bulgaria. Journal of Comparative Economics, 31(3):503-531, September 2003.

[49] Jun Qian and Philip E. Strahan. How laws and institutions shape financial contracts: The case of bank loans. Draft, May 2005.

[50] Raghuram G. Rajan and Luigi Zingales. Financial dependence and growth. American Economic Review, 88(3):559-586, June 1998.

[51] Felix Rioja and Neven Valev. Does one size fit all?: A reexamination of the finance and growth relationship. Journal of Development Economics, 74(2):429-447, August 2004.

[52] David Roodman. xtabond2: Stata module to extend xtabond dynamic panel data estimator. Center for Global Development, Washington, 2005.

[53] Paul N. Rosenstein-Rodan. Problems of industrialisation of eastern and south-eastern europe. Economic Journal, 53:202-211, June-September 1943.

[54] Peter L. Rousseau and Paul Wachtel. Financial intermediation and economic performance: Historical evidence from five industrialized countries. Journal of Money, Credit and Banking, 30(4):657-678, November 1998.

[55] Jeffrey Sachs. The End of Poverty: Economic Possibilities for our Time. Penguin Press, New York, 2005.

[56] Mehnaz S. Safavian. Corruption and microenterprises in Russia. Ph.D. Dissertation, The Ohio State University, 2001.

[57] Andrei Shleifer and Robert W. Vishny. Corruption. Quarterly Journal of Economics, 108(3):599-617, August 1993. 
[58] Jakob Svensson. Who must pay bribes and how much? Evidence from a cross section of firms. Quarterly Journal of Economics, 118(1):207-230, February 2003.

[59] Jakob Svensson. Eight questions about corruption. Journal of Economic Perspectives, 19(3):19-42, Summer 2005.

\section{A Substitutability when Bribes cannot be Borrowed}

The setup is the same as the baseline model except we assume that all firms have internal funds available for investment in the amount $W$, where

$$
\kappa J<W<(1+\kappa) J
$$

This assumption assures that internal funds are sufficient to pay the bribes, but insufficient to fund the entire cost of the investment project (capital plus bribes).

All firms will exhaust internal funds on investment before accessing external funds, which are more costly (strictly so if $\phi>0$ ). Thus, if they choose to invest, they use $W$ of their own funds (worth $R W$ in end-of-period terms) and borrow the remainder $(1+\kappa) J-W$ at interest rate $(1+\phi) R$. Note that since $W>\kappa J$, the amount borrowed is less than $J$. Thus none of the loan needs to go for bribery; it can all go toward legitimate investment purposes.

The end-of-period value of project $i$ is then

$$
Y_{i}-R W-(1+\phi) R[(1+\kappa) J-W]=Y_{i}-(1+\kappa)(1+\phi) R J+\phi R W .
$$

This is exactly the same as in the baseline model except the firm saves intermediation costs $\phi R$ proportional to its own funds, $W$. As before, the number of investment projects undertaken, $N_{I}$, equals $1-F\left(Y^{*}\right)$; here $Y^{*}=(1+\kappa)(1+\phi) R J-\phi R W . N_{I}$ continues to be lower the higher is $\phi$ or $\kappa$, though the effect of financial development here is mitigated by firms' access to internal funds:

$$
\frac{\partial N_{I}}{\partial \phi}=-f\left(Y^{*}\right)[(1+\kappa) R J-R W]<0 ; \quad \frac{\partial N_{I}}{\partial \kappa}=-f\left(Y^{*}\right)(1+\phi) R J<0 .
$$

The interactive effect is now

$$
\frac{\partial^{2} N_{I}}{\partial \phi \partial \kappa}=-f\left(Y^{*}\right) R J\left[\frac{f^{\prime}\left(Y^{*}\right) Y^{*}}{f\left(Y^{*}\right)}\left(\frac{Y^{*}-R W}{Y^{*}}\right)+1\right] .
$$

This is exactly as in equation 6 if $W=0$. The condition guaranteeing substitutability is

$$
\frac{f^{\prime}\left(Y^{*}\right) Y^{*}}{f\left(Y^{*}\right)}>-\frac{Y^{*}}{Y^{*}-R W}
$$

which involves a less restrictive bound when $W$ is in the assumed range than the bound required for proposition 1 , i.e. -1 .

Thus it is not crucial that firms be able to borrow in order to pay bribes. Even if they only pay corrupt fees using their own money, the higher these fees are the greater their need 
for external financing for investment, and the same logic applies. ${ }^{40}$

\footnotetext{
${ }^{40} \mathrm{~A}$ more complex but similar condition guarantees substitutability if firms vary in the amount of internal funds available, $W_{i}$. Necessary for this condition to hold is that there is a positive measure of firms with $W_{i} \in[\kappa J,(1+\kappa) J]$. The reason is that only for these firms does higher corruption raise borrowing needs. Firms with $W_{i}<\kappa J$ cannot fund a project regardless of its worth (since banks do not fund bribery) and so do not borrow; and firms with $W_{i}>(1+\kappa) J$ have enough funds so that they do not need to borrow.
} 
Table 1 - Description and Summary Statistics of Focal Variables

\begin{tabular}{|c|c|c|c|c|c|c|}
\hline Variable & Mean & Median & Std. Dev. & Minimum & Maximum & Obs. \\
\hline \multicolumn{7}{|c|}{ Country-Level Variables } \\
\hline Private_Credit & 0.367 & 0.286 & 0.265 & 0.047 & 1.251 & 71 \\
\hline Log_Real_Spread & 1.618 & 1.582 & 0.671 & -0.749 & 3.488 & 66 \\
\hline Corruption_ICRG & 3.537 & 3.255 & 1.329 & 1.083 & 6 & 71 \\
\hline Corruption_TI & 3.080 & 2.703 & 1.503 & 0.585 & 5.520 & 58 \\
\hline \multicolumn{7}{|c|}{ Industry-Level Variables } \\
\hline $\mathrm{F}$ & 0.319 & 0.231 & 0.406 & -0.451 & 1.492 & 36 \\
\hline I & 0.298 & 0.278 & 0.095 & 0.161 & 0.560 & 36 \\
\hline
\end{tabular}

Note: Private_Credit - Credit to private enterprises as a fraction of GDP. Log_Real_Spread - Log real spread between borrowing and saving interest rates. Corruption_ICRG - Corruption, International Country Risk Guide measure. Corruption_TI - Corruption, Transparency International measure. Corruption_TI is rescaled to range between 0-6. A higher number for either corruption measure implies less corruption. F - Financial Dependence $=$ one minus (cash flow / capital expenditures) of median U.S. firm. I - Investment Intensity = capital expenditures / (property, plant, and equipment) of median U.S. firm. 


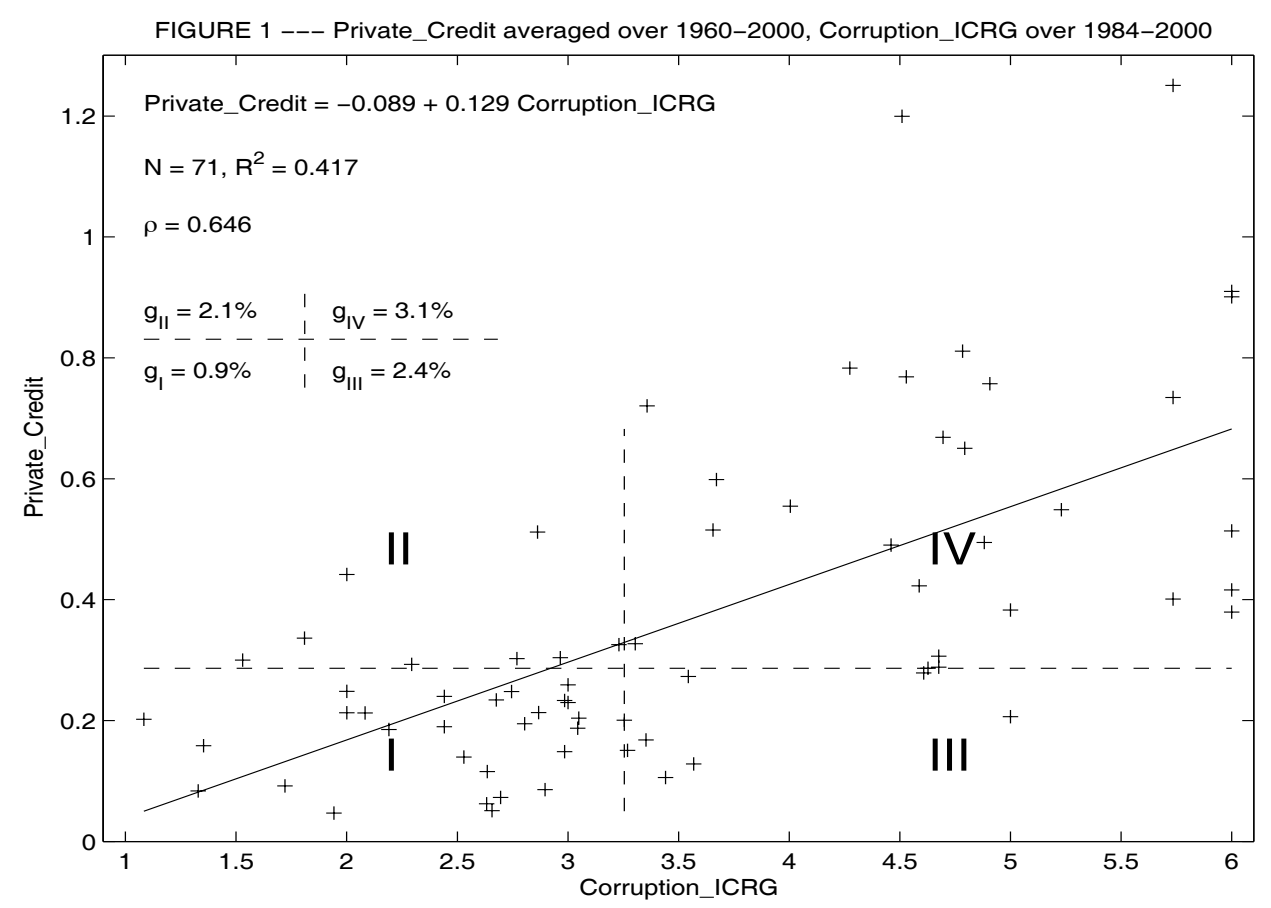

Figure 1: Scatterplot of Private_Credit versus Corruption_ICRG, with regression line. Dashed lines divide the data by each variable's median. Average real GDP/capita growth rates for each quadrant are reported. 


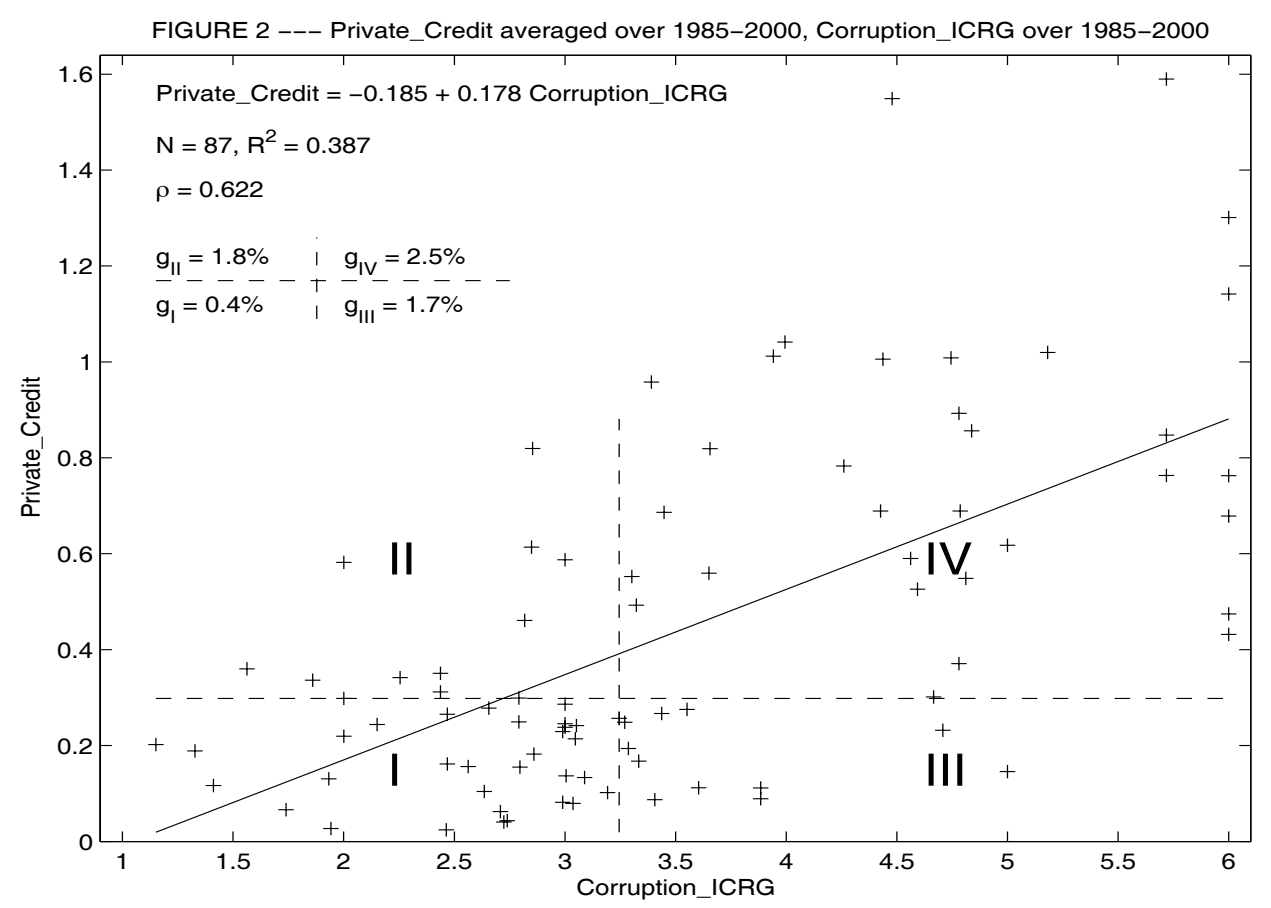

Figure 2: Scatterplot of Private_Credit versus Corruption_ICRG, with regression line. Dashed lines divide the data by each variable's median. Average real GDP/capita growth rates for each quadrant are reported. 
TABLE 2 - Cross-Country Analysis, 1960-2000

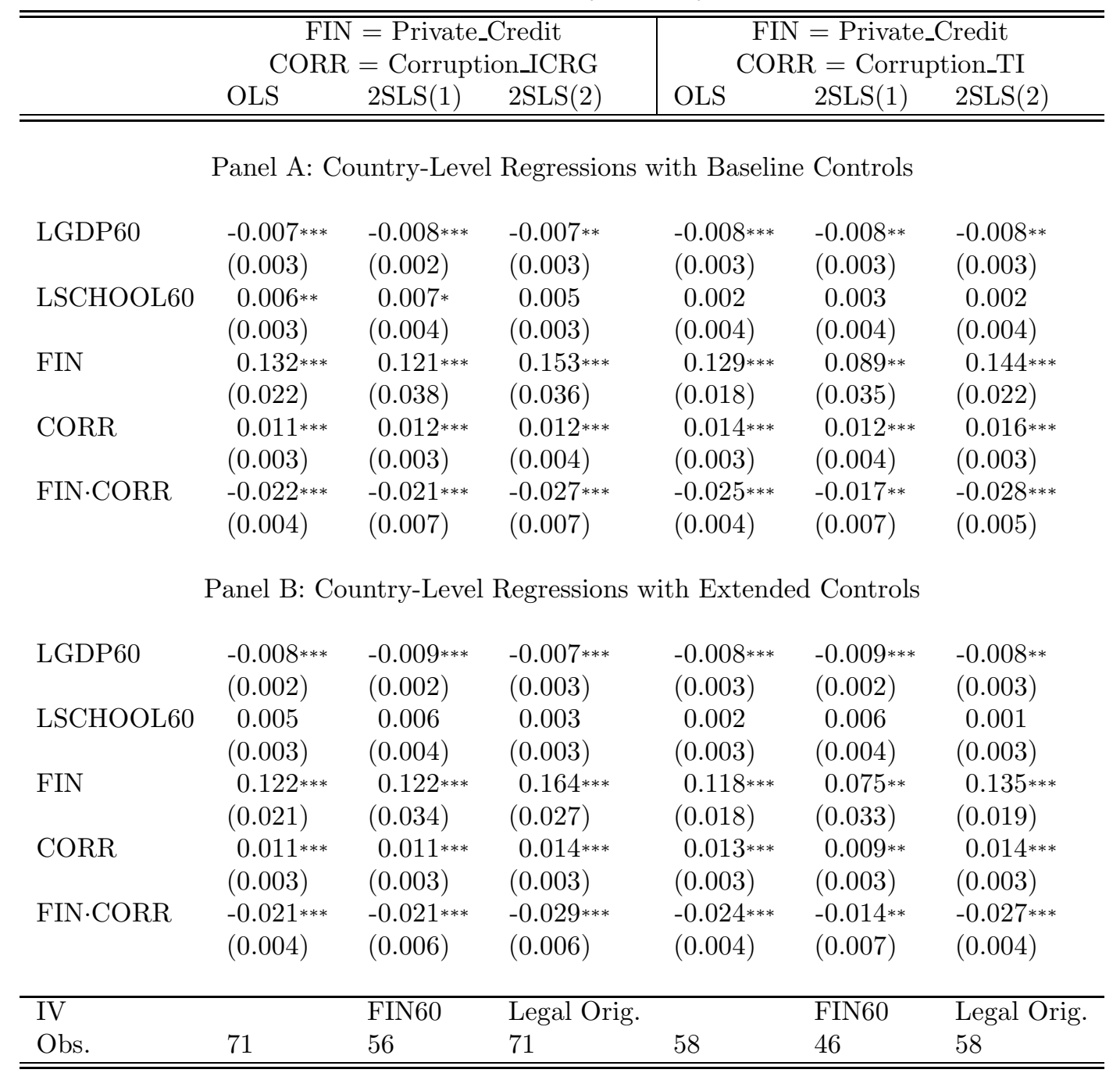

Note: Dependent variable is real GDP/capita growth over 1960-2000. Heteroskedasticity-robust standard errors in parentheses. Coefficients significant at 1\%,5\%, and $10 \%$ levels are denoted by ***, **, and *, respectively. LGDP60 = log real GDP/capita in 1960. LSCHOOL60 = log average school attainment in 1960. Additional regressors included in Panel B regressions are population growth rate, inflation, trade openness, and government expenditure. Corruption_ICRG is averaged over 1984-2000. Corruption_TI is averaged over 1980-2000. Instruments for FIN are its 1960 level, FIN60, in columns $2 \& 5$ and legal origin in columns $3 \& 6$. 


\section{TABLE 3 - Pooled Cross-Country Analysis, 1960-2000}

\begin{tabular}{l|l}
\hline \hline FIN $=$ Private_Credit & \multicolumn{2}{|c}{ FIN = Private_Credit } \\
CORR $=$ Corruption_ICRG & CORR = Corruption_TI \\
OLS $\quad$ 2SLS $(1)$ & OLS $\quad$ 2SLS $(1)$ \\
\hline \hline
\end{tabular}

Panel A: Pooled Country-Level Regressions with Baseline Controls

\begin{tabular}{lllll} 
ILGDP & $-0.006 * * *$ & $-0.005^{* *}$ & -0.003 & -0.001 \\
& $(0.002)$ & $(0.002)$ & $(0.002)$ & $(0.002)$ \\
ILSCHOOL & $0.008^{* * *}$ & $0.009^{* * *}$ & -0.005 & -0.004 \\
& $(0.002)$ & $(0.003)$ & $(0.005)$ & $(0.005)$ \\
FIN & $0.090^{* * *}$ & $0.077^{* * *}$ & $0.079^{* * *}$ & $0.047 * *$ \\
& $(0.019)$ & $(0.021)$ & $(0.015)$ & $(0.021)$ \\
CORR & $0.008^{* * *}$ & $0.008^{* *}$ & $0.010^{* * *}$ & $0.008^{* * *}$ \\
& $(0.002)$ & $(0.002)$ & $(0.002)$ & $(0.002)$ \\
FIN.CORR & $-0.015^{* * *}$ & $-0.013^{* * *}$ & $-0.015^{* * *}$ & $-0.010 * *$ \\
& $(0.004)$ & $(0.004)$ & $(0.003)$ & $(0.004)$ \\
& & & & \\
\hline IV & & IFIN & & IFIN \\
Obs. & 291 & 253 & 231 & 203 \\
\hline
\end{tabular}

Panel B: Pooled Country-Level Regressions with Extended Controls

\begin{tabular}{lllll} 
ILGDP & $-0.008^{* * *}$ & $-0.008^{* * *}$ & $-0.004 *$ & $-0.004 *$ \\
& $(0.002)$ & $(0.002)$ & $(0.002)$ & $(0.002)$ \\
ILSCHOOL & $0.007 * * *$ & $0.010 * * *$ & -0.003 & 0.000 \\
& $(0.002)$ & $(0.002)$ & $(0.005)$ & $(0.004)$ \\
FIN & $0.082^{* * *}$ & $0.068^{* * *}$ & $0.072^{* * *}$ & $0.039^{* * *}$ \\
& $(0.017)$ & $(0.019)$ & $(0.015)$ & $(0.019)$ \\
CORR & $0.009^{* * *}$ & $0.009^{* * *}$ & $0.010^{* * *}$ & $0.006^{* *}$ \\
& $(0.002)$ & $(0.002)$ & $(0.003)$ & $(0.002)$ \\
FIN.CORR & $-0.014^{* * *}$ & $-0.013^{* * *}$ & $-0.015^{* * *}$ & $-0.008 * *$ \\
& $(0.003)$ & $(0.003)$ & $(0.003)$ & $(0.004)$ \\
& & & & \\
\hline IV & & IFIN & 223 & 197 \\
Obs. & 281 & 245 & & IFIN \\
\hline \hline
\end{tabular}

Note: Dependent variable is real GDP/capita growth over a decade. Heteroskedasticity-robust standard errors in parentheses. Coefficients significant at 1\%, 5\%, and $10 \%$ levels are denoted by ***, **, and *, respectively. All independent variables correspond to decades; the exceptions are Corruption_ICRG, averaged over 1984-2000, and Corruption_TI, averaged over 1980-2000. Decade dummies are included. ILGDP = decade-initial log real GDP/capita. ILSCHOOL = decade-initial log average school attainment. Additional regressors included in Panel B regressions are population growth rate, inflation, trade openness, and government expenditure. FIN is instrumented by its decade-initial value, IFIN, in the 2SLS specifications. 
TABLE 4 - Pooled and Panel Cross-Country Analysis, 1980-2000

\begin{tabular}{|c|c|c|c|c|}
\hline & \multicolumn{2}{|c|}{$\begin{array}{c}\text { FIN }=\text { Private_Credit } \\
\text { CORR }=\text { Corruption_ICRG } \\
\text { Baseline Controls Included }\end{array}$} & \multicolumn{2}{|c|}{$\begin{array}{c}\text { FIN }=\text { Private_Credit } \\
\text { CORR = Corruption_ICRG } \\
\text { Extended Controls Included }\end{array}$} \\
\hline & \multicolumn{4}{|c|}{ Panel A: Pooled Country-Level Regressions } \\
\hline & OLS & 2SLS(1) & OLS & 2SLS(1) \\
\hline ILGDP & $\begin{array}{l}-0.002 \\
(0.002)\end{array}$ & $\begin{array}{l}-0.002 \\
(0.002)\end{array}$ & $\begin{array}{l}-0.003 \\
(0.002)\end{array}$ & $\begin{array}{l}-0.004^{*} \\
(0.002)\end{array}$ \\
\hline ILSCHOOL & $\begin{array}{l}0.008 * * \\
(0.004)\end{array}$ & $\begin{array}{r}0.008^{*} \\
(0.004)\end{array}$ & $\begin{array}{c}0.005 \\
(0.003)\end{array}$ & $\begin{array}{c}0.005 \\
(0.003)\end{array}$ \\
\hline FIN & $\begin{array}{l}0.049 * * * \\
(0.019)\end{array}$ & $\begin{array}{l}0.058 * * * \\
(0.020)\end{array}$ & $\begin{array}{l}0.044 * * * \\
(0.019)\end{array}$ & $\begin{array}{c}0.055^{* *} \\
(0.022)\end{array}$ \\
\hline CORR & $\begin{array}{c}0.004 * \\
(0.002)\end{array}$ & $\begin{array}{l}0.006^{* * *} \\
(0.003)\end{array}$ & $\begin{array}{l}0.005^{* *} \\
(0.002)\end{array}$ & $\begin{array}{l}0.007 * * * \\
(0.003)\end{array}$ \\
\hline FIN. CORR & $\begin{array}{l}-0.008 * * \\
(0.004)\end{array}$ & $\begin{array}{l}-0.011^{* * *} \\
(0.004)\end{array}$ & $\begin{array}{l}-0.008^{* *} \\
(0.004)\end{array}$ & $\begin{array}{l}-0.011 * * * \\
(0.004)\end{array}$ \\
\hline IV & & IFIN, ICORR & & IFIN, ICORR \\
\hline Obs. & 330 & 311 & 330 & 311 \\
\hline
\end{tabular}

Panel B: System GMM Regressions

\begin{tabular}{lcccc} 
ILGDP & 0.009 &. & 0.006 &. \\
& $(0.007)$ &. & $(0.005)$ &. \\
ILSCHOOL & 0.006 &. & 0.007 &. \\
& $(0.011)$ &. & $(0.011)$ &. \\
FIN & $0.099 * * *$ &. & $0.082^{* *}$ &. \\
& $(0.029)$ &. & $(0.034)$ &. \\
CORR & 0.004 &. & $0.008 * *$ &. \\
& $(0.005)$ &. & $(0.004)$ &. \\
FIN. CORR & $-0.022^{* * *}$ &. & $-0.018 * *$ &. \\
& $(0.007)$ &. & $0.007)$ &. \\
& & & 0.179 & \\
\hline Hansen's J test & 0.281 & & 0.225 & \\
AR(2) test & 0.119 & & 330 \\
Obs. & 330 & & \\
\hline \hline
\end{tabular}

Note: Dependent variable is real GDP/capita growth over a half-decade. Heteroskedasticity-robust standard errors in parentheses. Coefficients significant at $1 \%, 5 \%$, and $10 \%$ levels are denoted by $* * *$, **, and *, respectively. All independent variables correspond to half-decades; the exception is Corruption_ICRG for the first half-decade, for which it is averaged over 1984-1985. Half-decade dummies are included. ILGDP $=$ half-decade initial $\log$ real GDP/capita. ILSCHOOL = half-decade initial log average school attainment. Additional regressors included in Panel B regressions are population growth rate, inflation, trade openness, and government expenditure. FIN and CORR are instrumented by their half-decade initial values, IFIN and ICORR, respectively, in the 2SLS specifications. The null hypothesis of Hansen's J test is that the instruments used are not correlated with the residuals. The null hypothesis of the AR(2) test is that the errors in the first-difference regression exhibit no second-order serial correlation (there is first-order serial correlation by construction). P-values of the two tests are reported. 
TABLE 5 - Cross-Country Analysis of Growth Sources over 1960-1995

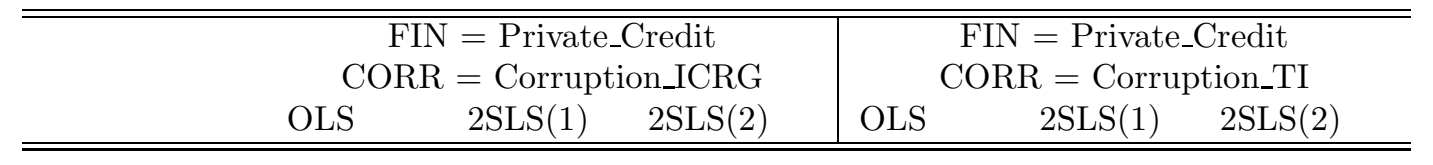

Panel A: Dependent Variable $=$ Growth Rate of Physical Capital

$\begin{array}{lcccccc}\text { LGDP60 } & -0.013^{* *} & -0.008 & -0.011^{*} & -0.014^{*} & -0.013 * & -0.012 \\ & (0.006) & (0.007) & (0.006) & (0.007) & (0.007) & (0.009) \\ \text { LSCHOOL60 } & 0.014 & 0.011 & 0.009 & 0.011 & 0.005 & 0.010 \\ & (0.009) & (0.011) & (0.010) & (0.007) & (0.008) & (0.008) \\ \text { FIN } & 0.110 * * & 0.015 & 0.180 * & 0.209 * * * & 0.163 * * * & 0.310^{* * *} \\ & (0.048) & (0.066) & (0.093) & (0.036) & (0.044) & (0.036) \\ \text { CORR } & 0.005 & 0.003 & 0.006 & 0.007 * * * & 0.007 * * * & 0.008 * * * \\ & (0.004) & (0.005) & (0.005) & (0.002) & (0.002) & (0.002) \\ \text { FIN.CORR } & -0.016 * & -0.002 & -0.027 & -0.020^{* * *} & -0.016 * * * & -0.029 * * * \\ & (0.009) & (0.011) & (0.016) & (0.004) & (0.004) & (0.004)\end{array}$

Panel B: Dependent Variable $=$ Growth Rate of Productivity

\begin{tabular}{lllllll} 
LGDP60 & $-0.009 * *$ & $-0.013^{* * *}$ & $-0.008 *$ & $-0.010 * *$ & $-0.011^{* * *}$ & $-0.009 * *$ \\
& $(0.004)$ & $(0.003)$ & $(0.004)$ & $(0.004)$ & $(0.003)$ & $(0.004)$ \\
LSCHOOL60 & $0.013^{* *}$ & 0.006 & 0.010 & 0.000 & -0.001 & 0.000 \\
& $(0.006)$ & $(0.006)$ & $(0.007)$ & $(0.004)$ & $(0.004)$ & $(0.005)$ \\
FIN & $0.100 * *$ & $0.117 * * *$ & $0.134^{* * *}$ & $0.052^{* * *}$ & $0.064^{* * *}$ & $0.078 * * *$ \\
& $(0.020)$ & $(0.030)$ & $(0.024)$ & $(0.017)$ & $(0.021)$ & $(0.021)$ \\
CORR & $0.007 * * *$ & $0.011^{* * *}$ & $0.008^{* * *}$ & $0.003^{* * *}$ & $0.004^{* * *}$ & $0.004^{* * *}$ \\
& $(0.002)$ & $(0.002)$ & $(0.002)$ & $(0.001)$ & $(0.001)$ & $(0.001)$ \\
FIN.CORR & $-0.018^{* * *}$ & $-0.021^{* * *}$ & $-0.023^{* * *}$ & $-0.005^{* * *}$ & $-0.006^{* * *}$ & $-0.007 * *$ \\
& $(0.004)$ & $(0.005)$ & $(0.004)$ & $(0.002)$ & $(0.002)$ & $(0.002)$ \\
& & & & & & \\
\hline IV & & FIN60 & Legal Orig. & & FIN60 & Legal Orig. \\
Obs. & 64 & 54 & 39 & 35 & 39 \\
\hline \hline
\end{tabular}

Note: Dependent variable is capital stock growth rate in Panel A and productivity growth rate in Panel B. Heteroskedasticity-robust standard errors in parentheses. Coefficients significant at 1\%, 5\%, and $10 \%$ levels are denoted by ${ }^{* * *},{ }^{* *}$, and $*$, respectively. LGDP60 $=\log$ real GDP/capita in 1960. LSCHOOL60 $=\log$ average school attainment in 1960. Corruption_ICRG is averaged over 1984-1995. Corruption_TI is the average of the 1980-1985 measure and the 1988-1992 measure. Instruments for FIN are its 1960 level, FIN60, in columns $2 \& 5$ and legal origin in columns $3 \& 6$. 
TABLE 6 - Industry Analysis, 1980-1989

\begin{tabular}{|c|c|c|c|c|c|c|}
\hline & \multicolumn{3}{|c|}{$\begin{array}{c}\text { FIN }=\text { Private_Credit } \\
\text { CORR }=\text { Corruption_ICRG }\end{array}$} & \multicolumn{3}{|c|}{$\begin{array}{c}\text { FIN }=\text { Private_Credit } \\
\text { CORR }=\text { Corruption_TI }\end{array}$} \\
\hline & OLS & 2SLS(1) & $2 \operatorname{SLS}(2)$ & OLS & $2 \mathrm{SLS}(1)$ & $2 \mathrm{SLS}(2)$ \\
\hline SHARE80 & $\begin{array}{l}-0.807 * * * \\
(0.200)\end{array}$ & $\begin{array}{l}-0.798^{* * *} \\
(0.205)\end{array}$ & $\begin{array}{l}-0.795^{* * *} \\
(0.199)\end{array}$ & $\begin{array}{l}-0.805^{* * *} \\
(0.220)\end{array}$ & $\begin{array}{l}-0.792^{* * *} \\
(0.224)\end{array}$ & $\begin{array}{l}-0.812^{* * *} \\
(0.220)\end{array}$ \\
\hline FIN·D & $\begin{array}{l}0.214 * * * \\
(0.080)\end{array}$ & $\begin{array}{l}0.232^{* * *} \\
(0.088)\end{array}$ & $\begin{array}{l}0.186 * * \\
(0.086)\end{array}$ & $\begin{array}{l}0.194 * * * \\
(0.075)\end{array}$ & $\begin{array}{l}0.212^{* *} \\
(0.084)\end{array}$ & $\begin{array}{l}0.229 * * \\
(0.092)\end{array}$ \\
\hline $\mathrm{CORR} \cdot \mathrm{I}$ & $\begin{array}{l}0.109 * * * \\
(0.041)\end{array}$ & $\begin{array}{l}0.120^{* * *} \\
(0.043)\end{array}$ & $\begin{array}{l}0.108^{* *} \\
(0.046)\end{array}$ & $\begin{array}{l}0.132^{* * *} \\
(0.048)\end{array}$ & $\begin{array}{l}0.140 * * * \\
(0.049)\end{array}$ & $\begin{array}{l}0.142^{* * *} \\
(0.052)\end{array}$ \\
\hline FIN.D.CORR·I & $\begin{array}{l}-0.079 * * \\
(0.034)\end{array}$ & $\begin{array}{l}-0.087 * * \\
(0.037)\end{array}$ & $\begin{array}{l}-0.072^{*} \\
(0.037)\end{array}$ & $\begin{array}{l}-0.089 * * \\
(0.037)\end{array}$ & $\begin{array}{l}-0.097 * * \\
(0.041)\end{array}$ & $\begin{array}{l}-0.106 * * \\
(0.045)\end{array}$ \\
\hline IV & & FIN80 & Legal Orig. & & FIN80 & Legal Orig. \\
\hline Obs. & 1183 & 1111 & 1183 & 1099 & 1027 & 1099 \\
\hline
\end{tabular}

Note: Dependent variable is growth rate of industry value added over 1980-1989. Heteroskedasticity-robust standard errors in parentheses. Coefficients significant at 1\%, $5 \%$, and $10 \%$ levels are denoted by ***, ${ }^{* *}$, and *, respectively. SHARE80 = industry's share of country's industrial value added in 1980. D = industry-level financial dependence. I = industry-level investment intensity. Corruption_ICRG is averaged over 1984-1989. Corruption_TI is the average of the 1980-1985 measure and the 1988-1992 measure. Country and industry dummies are included. Instruments for FIN are its 1980 level, FIN80, in columns $2 \& 5$ and legal origin in columns $3 \& 6$. 
TABLE 7 - Cross-Country and Industry Analysis excluding Outliers

\begin{tabular}{|c|c|c|}
\hline & $\begin{array}{c}\mathrm{FIN}=\text { Private_Credit } \\
\mathrm{ORR}=\text { Corruption_ICRG }\end{array}$ & $\begin{array}{c}\text { FIN = Private_Credit } \\
\text { CORR = Corruption_TI }\end{array}$ \\
\hline OLS & $2 \mathrm{SLS}(1) \quad 2 \mathrm{SLS}(2)$ & OLS $\quad 2 \operatorname{SLS}(1) \quad 2 \operatorname{SLS}(2)$ \\
\hline
\end{tabular}

Panel A: Country-Level Regressions with Baseline Controls

$\begin{array}{lllllll}\text { FIN } & 0.126 * * * & 0.117^{* *} & 0.121^{* *} & 0.125 * * & 0.075^{*} & 0.140^{* * *} \\ & (0.023) & (0.047) & (0.047) & (0.021) & (0.040) & (0.026) \\ \text { CORR } & 0.010^{* * *} & 0.011^{* * *} & 0.006 & 0.014^{* * *} & 0.010^{* *} & 0.015^{* * *} \\ & (0.003) & (0.004) & (0.006) & (0.004) & (0.004) & (0.003) \\ \text { FIN.CORR } & -0.019 * * * & -0.019^{* *} & -0.013 & -0.023^{* * *} & -0.012 & -0.027^{* * *} \\ & (0.005) & (0.008) & (0.012) & (0.006) & (0.008) & (0.006)\end{array}$

Panel B: Country-Level Regressions with Extended Controls

\begin{tabular}{lllllll} 
FIN & $0.116^{* * *}$ & $0.114 * *$ & $0.127 * * *$ & $0.116^{* * *}$ & 0.058 & $0.133^{* * *}$ \\
& $(0.022)$ & $(0.044)$ & $(0.039)$ & $(0.021)$ & $(0.036)$ & $(0.025)$ \\
CORR & $0.010^{* * *}$ & $0.010 * *$ & 0.007 & $0.013^{* * *}$ & $0.006^{*}$ & $0.014^{* * *}$ \\
& $(0.003)$ & $(0.004)$ & $(0.004)$ & $(0.004)$ & $(0.004)$ & $(0.004)$ \\
FIN.CORR & $-0.019^{* * *}$ & $-0.019 * *$ & -0.015 & $-0.024 * * *$ & -0.009 & $-0.027^{* * *}$ \\
& $(0.004)$ & $(0.009)$ & $(0.009)$ & $(0.005)$ & $(0.008)$ & $(0.006)$ \\
& & & & & \\
\hline IV & & FIN60 & Legal Orig. & & FIN60 & Legal Orig. \\
Obs. & 69 & 54 & 69 & 56 & 44 & 56 \\
\hline
\end{tabular}

Panel C: Industry-Level Regressions

\begin{tabular}{lllllll} 
FIN.D & $0.265^{* * *}$ & $0.295^{* * *}$ & $0.255^{* *}$ & $0.235^{* * *}$ & $0.259^{* * *}$ & $0.281^{* * *}$ \\
& $(0.093)$ & $(0.104)$ & $(0.103)$ & $(0.084)$ & $(0.095)$ & $(0.107)$ \\
CORR.I & $0.110 * *$ & $0.126^{* * *}$ & $0.101^{*}$ & $0.134^{* * *}$ & $0.143^{* * *}$ & $0.141^{* *}$ \\
& $(0.044)$ & $(0.046)$ & $(0.051)$ & $(0.051)$ & $(0.052)$ & $(0.057)$ \\
FIN.D.CORR.I & $-0.090^{* *}$ & $-0.104 * *$ & $-0.081^{*}$ & $-0.099^{* *}$ & $-0.109^{* *}$ & $-0.116^{* *}$ \\
& $(0.038)$ & $(0.042)$ & $(0.041)$ & $(0.041)$ & $(0.045)$ & $(0.050)$ \\
& & & & FIN80 & Legal Orig. \\
\hline IV & & FIN80 & Legal Orig. & & 978 & 1050 \\
\hline \hline
\end{tabular}

Note: Dependent variables are real GDP/capita growth over 1960-2000 in Panels A\&B and growth rate of industry value added over 1980-1989 in Panel C. Heteroskedasticity-robust standard errors in parentheses. Coefficients significant at 1\%,5\%, and 10\% levels are denoted by ***,**, and *, respectively. Regressors included in Panel A and B regressions are log real GDP per capita in 1960 and log average school attainment in 1960. Additional regressors included in Panel B regressions are population growth rate, inflation, trade openness, and government expenditure. Regressors included in Panel $\mathrm{C}$ regressions are initial industry share and country and industry dummies. $\mathrm{D}=$ industry-level financial dependence. $\mathrm{I}=$ industry-level investment intensity. Corruption_ICRG is averaged over 1984-2000 for panel A and B regressions and over 1984-1989 for panel C regressions. Corruption_TI is averaged over 1980-2000 for panel A and B regressions and is the average of the 1980-1985 measure and the 1988-1992 measure for panel C regressions. Instruments for FIN are its 1960 level, FIN60, in columns 2\&5 of Panels A and B, its 1980 level, FIN80, in columns 2\&5 of Panel $\mathrm{C}$, and legal origin in columns $3 \& 6$. All regressions exclude countries with Private_Credit $>1$. 


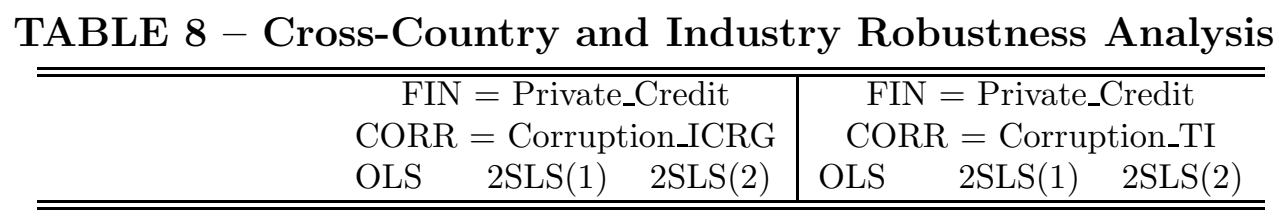

Panel A: Country-Level Regressions with Baseline Controls

$\begin{array}{lllllll}\text { Coefficient } & -0.022 & -0.021 & -0.027 & -0.025 & -0.017 & -0.028 \\ \text { T-stat } & -4.88 & -3.13 & -3.71 & -5.56 & -2.41 & -6.06 \\ \text { Coefficient_MIN } & -0.019 & -0.018 & -0.016 & -0.022 & -0.012 & -0.020 \\ \text { T-stat_MIN } & -4.02 & -2.34 & -1.34 & -4.00 & -1.28 & -2.57 \\ \text { Coefficient_MAX } & -0.023 & -0.024 & -0.029 & -0.027 & -0.021 & -0.032 \\ \text { T-stat_MAX } & -5.50 & -3.58 & -4.65 & -6.86 & -4.37 & -10.7\end{array}$

Panel B: Country-Level Regressions with Extended Controls

$\begin{array}{lllllll}\text { Coefficient } & -0.021 & -0.021 & -0.029 & -0.024 & -0.014 & -0.027 \\ \text { T-stat } & -5.15 & -3.46 & -5.26 & -5.79 & -2.10 & -6.92 \\ \text { Coefficient_MIN } & -0.019 & -0.018 & -0.021 & -0.022 & -0.009 & -0.023 \\ \text { T-stat_MIN } & -4.37 & -2.29 & -2.07 & -4.42 & -1.20 & -3.66 \\ \text { Coefficient_MAX } & -0.023 & -0.025 & -0.031 & -0.026 & -0.019 & -0.030 \\ \text { T-stat_MAX } & -6.26 & -4.08 & -5.98 & -6.60 & -3.27 & -11.1\end{array}$

Panel C: Industry-Level Regressions

\begin{tabular}{lllllll} 
Coefficient & -0.079 & -0.087 & -0.072 & -0.089 & -0.097 & -0.106 \\
T-stat & -2.34 & -2.38 & -1.95 & -2.40 & -2.38 & -2.37 \\
Coefficient_MIN & -0.032 & -0.031 & -0.021 & -0.030 & -0.026 & -0.048 \\
T-stat_MIN & -1.22 & -1.16 & -0.798 & -1.13 & -1.00 & -1.46 \\
Coefficient_MAX & -0.087 & -0.099 & -0.080 & -0.102 & -0.118 & -0.115 \\
T-stat_MAX & -2.49 & -2.61 & -2.13 & -2.61 & -2.68 & -2.53 \\
\hline \hline
\end{tabular}

Note: This table contains coefficients and t-statistics for the CORR. FIN interaction term from a number of specifications. Panels A\&B are from the same specifications as Panels A\&B of Table 2; Panel $\mathrm{C}$ is from the same specification as Table 6 . The coefficients and t-statistics from those Tables are reproduced here, along with the maximum and minimum coefficients and t-statistics (in absolute value) that result from dropping one country from each regression. 


\section{TABLE 9 - Cross-Country and Industry Analysis Using Corruption_KKM}

\begin{tabular}{|c|c|c|c|}
\hline & \multicolumn{3}{|c|}{$\begin{array}{l}\text { FIN = Private_Credit } \\
\text { CORR = Corruption_KKM }\end{array}$} \\
\hline & \multicolumn{3}{|c|}{ Panel A: Country-Level Regressions with Baseline Controls } \\
\hline FIN & $\begin{array}{l}0.057 * * * \\
(0.008)\end{array}$ & $\begin{array}{r}0.052^{*} \\
(0.027)\end{array}$ & $\begin{array}{l}0.081 * * * \\
(0.008)\end{array}$ \\
\hline CORR & $\begin{array}{l}0.020 * * * \\
(0.003)\end{array}$ & $\begin{array}{l}0.017 * * * \\
(0.004)\end{array}$ & $\begin{array}{l}0.024 * * * \\
(0.003)\end{array}$ \\
\hline \multirow[t]{2}{*}{ FIN·CORR } & $\begin{array}{l}-0.026 * * * \\
(0.005)\end{array}$ & $\begin{array}{l}-0.023^{*} \\
(0.012)\end{array}$ & $\begin{array}{l}-0.039 * * * \\
(0.005)\end{array}$ \\
\hline & \multicolumn{3}{|c|}{ Panel B: Country-Level Regressions with Extended Controls } \\
\hline FIN & $\begin{array}{l}0.054^{* * *} \\
(0.008)\end{array}$ & $\begin{array}{c}0.061 * * \\
(0.028)\end{array}$ & $\begin{array}{l}0.078 * * * \\
(0.008)\end{array}$ \\
\hline CORR & $\begin{array}{l}0.019 * * * \\
(0.004)\end{array}$ & $\begin{array}{l}0.015 * * * \\
(0.004)\end{array}$ & $\begin{array}{l}0.023^{* * *} \\
(0.004)\end{array}$ \\
\hline FIN·CORR & $\begin{array}{l}-0.027 * * * \\
(0.005)\end{array}$ & $\begin{array}{l}-0.027 * * \\
(0.012)\end{array}$ & $\begin{array}{l}-0.039 * * * \\
(0.005)\end{array}$ \\
\hline IV & & FIN60 & Legal Orig. \\
\hline Obs. & 76 & 58 & 76 \\
\hline
\end{tabular}

Panel C: Industry-Level Regressions

\begin{tabular}{llll} 
FIN.D & $0.118^{* *}$ & $0.123^{* *}$ & 0.076 \\
& $(0.049)$ & $(0.049)$ & $(0.046)$ \\
CORR.I & $0.155^{* *}$ & $0.165^{* *}$ & $0.151^{* *}$ \\
& $(0.062)$ & $(0.065)$ & $(0.067)$ \\
FIN.D.CORR.I & $-0.123^{* *}$ & $-0.130^{* *}$ & -0.096 \\
& $(0.061)$ & $(0.063)$ & $(0.059)$ \\
& & & \\
\hline IV & & FIN80 & Legal Orig. \\
Obs. & 1216 & 1144 & 1216 \\
\hline \hline
\end{tabular}

Note: Dependent variables are real GDP/capita growth over 1960-2000 in Panels A\&B and growth rate of industry value added over 1980-1989 in Panel C. Corruption_KKM is the Kaufmann et al. (2006) measure of corruption averaged over 1996-2000; see section 5.2. Heteroskedasticity-robust standard errors in parentheses. Coefficients significant at $1 \%, 5 \%$, and $10 \%$ levels are denoted by $* * *, * *$, and ${ }^{*}$, respectively. $\mathrm{D}=$ industrylevel financial dependence. I = industry-level investment intensity. Instruments for FIN are its 1960 level, FIN60, in column 2 of Panels A and B, its 1980 level, FIN80, in column 2 of Panel C, and legal origin in column 3. See note to Table 7 for information on unreported regressors. 
TABLE 10 - Cross-Country and Industry Analysis using Log_Real_Spread

\begin{tabular}{c|l}
\hline \hline FIN = Log_Real_Spread & FIN = Log_Real_Spread \\
CORR = Corruption_ICRG & CORR = Corruption_TI \\
OLS $\quad$ 2SLS $(2)$ & OLS $\quad$ 2SLS $(2)$ \\
\hline \hline
\end{tabular}

Panel A: Country-Level Regressions with Baseline Controls

$\begin{array}{lllll}\text { FIN } & -0.036^{* * *} & -0.059 * * * & -0.028^{* * *} & -0.043^{* * *} \\ & (0.010) & (0.011) & (0.008) & (0.007) \\ \text { CORR } & -0.014^{* * *} & -0.021^{* * *} & -0.009^{* *} & -0.014^{* * *} \\ & (0.005) & (0.006) & (0.004) & (0.005) \\ \text { FIN.CORR } & 0.008^{* * *} & 0.012^{* * *} & 0.007 * * * & 0.010^{* * *} \\ & (0.002) & (0.003) & (0.002) & (0.003)\end{array}$

Panel B: Country-Level Regressions with Extended Controls

\begin{tabular}{lllll} 
FIN & $-0.043^{* * *}$ & $-0.045^{* *}$ & $-0.033^{* * *}$ & $-0.044^{* * *}$ \\
& $(0.011)$ & $(0.022)$ & $(0.009)$ & $(0.010)$ \\
CORR & $-0.015^{* * *}$ & -0.012 & $-0.009^{* *}$ & $-0.011^{* *}$ \\
& $(0.005)$ & $(0.010)$ & $(0.004)$ & $(0.005)$ \\
FIN.CORR & $0.009^{* * *}$ & 0.008 & $0.009^{* * *}$ & $0.010^{* *}$ \\
& $(0.003)$ & $(0.006)$ & $(0.002)$ & $(0.004)$ \\
& & & \\
\hline IV & 66 & 66 & 55 & 55 \\
Obs. & & Legal Orig. &
\end{tabular}

Panel C: Industry-Level Regressions

\begin{tabular}{lllll} 
FIN.D & 0.014 & -0.035 & 0.031 & -0.012 \\
& $(0.021)$ & $(0.028)$ & $(0.027)$ & $(0.032)$ \\
CORR.I & $0.100 * *$ & 0.116 & $0.147 * *$ & $0.162 *$ \\
& $(0.049)$ & $(0.71)$ & $(0.065)$ & $(0.088)$ \\
FIN.D.CORR.I & -0.008 & -0.010 & -0.019 & -0.021 \\
& $(0.010)$ & $(0.021)$ & $(0.014)$ & $(0.025)$ \\
& & & \\
\hline IV & & Legal Orig. & Legal Orig. \\
Obs. & 809 & 809 & 749 & 749 \\
\hline \hline
\end{tabular}

Note: Dependent variables are real GDP/capita growth over 1960-2000 in Panels A\&B and growth rate of industry value added over 1980-1989 in Panel C. Log_Real_Spread is the log of the real spread between the lending and saving interest rates; see section 5.2. Heteroskedasticity-robust standard errors in parentheses. Coefficients significant at $1 \%, 5 \%$, and $10 \%$ levels are denoted by $* * *, * *$, and ${ }^{*}$, respectively. $\mathrm{D}=$ industrylevel financial dependence. I = industry-level investment intensity. The instrument for FIN is legal origin in columns $2 \& 4$. See note to Table 7 for information on unreported regressors and corruption variable averages. 


\section{TABLE 11 - Cross-Country and Industry Analysis using Stock_Traded}

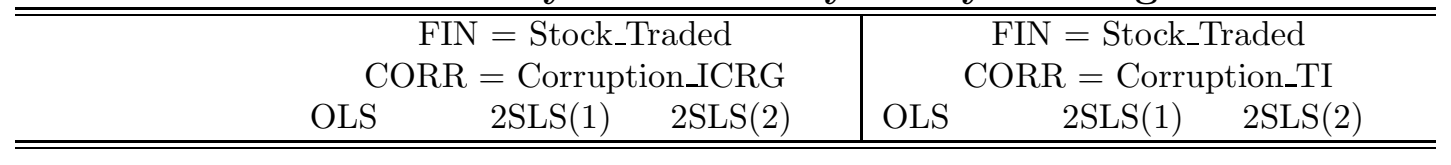

Panel A: Country-Level Regressions with Baseline Controls (1980-2000)

$\begin{array}{lllllll}\text { FIN } & 0.140 * * & 0.195 * * * & 0.216 * * * & 0.170 * * * & 0.105 * & 0.191 * * * \\ & (0.063) & (0.054) & (0.052) & (0.033) & (0.057) & (0.037) \\ \text { CORR } & 0.008 * & 0.005^{*} & 0.009 * & 0.005^{* *} & 0.004 & 0.006^{* *} \\ & (0.004) & (0.003) & (0.005) & (0.002) & (0.003) & (0.003) \\ \text { FIN.CORR } & -0.025^{* *} & -0.035^{* * *} & -0.038^{* * *} & -0.033^{* * *} & -0.020 * & -0.038^{* * *} \\ & (0.012) & (0.009) & (0.009) & (0.007) & (0.012) & (0.007)\end{array}$

Panel B: Country-Level Regressions with Extended Controls (1980-2000)

\begin{tabular}{|c|c|c|c|c|c|c|}
\hline FIN & $\begin{array}{l}0.184 * * * \\
(0.035)\end{array}$ & $\begin{array}{c}0.199 * * * \\
(0.065)\end{array}$ & $\begin{array}{l}0.226^{* * *} \\
(0.050)\end{array}$ & $\begin{array}{c}0.158^{* * *} \\
(0.029)\end{array}$ & $\begin{array}{c}0.138 * * \\
(0.052)\end{array}$ & $\begin{array}{l}0.156^{* * *} \\
(0.042)\end{array}$ \\
\hline CORR & $\begin{array}{c}0.006^{* *} \\
(0.003)\end{array}$ & $\begin{array}{c}0.003 \\
(0.003)\end{array}$ & $\begin{array}{r}0.006 * \\
(0.003)\end{array}$ & $\begin{array}{c}0.003 \\
(0.003)\end{array}$ & $\begin{array}{c}0.002 \\
(0.003)\end{array}$ & $\begin{array}{c}0.003 \\
(0.003)\end{array}$ \\
\hline FIN.CORR & $\begin{array}{l}-0.033^{* * *} \\
(0.006)\end{array}$ & $\begin{array}{l}-0.036^{* * *} \\
(0.011)\end{array}$ & $\begin{array}{l}-0.040 * * \\
(0.008)\end{array}$ & $\begin{array}{l}-0.031^{* * *} \\
(0.006)\end{array}$ & $\begin{array}{l}-0.027 * * * \\
(0.010)\end{array}$ & $\begin{array}{l}-0.031 * * * \\
(0.007)\end{array}$ \\
\hline IV & & FIN80 & Legal Orig. & & FIN80 & Legal Orig \\
\hline Obs. & 49 & 39 & 49 & 48 & 40 & 48 \\
\hline
\end{tabular}

Panel C: Industry-Level Regressions

\begin{tabular}{lllllll} 
FIN.D & $0.782^{* * *}$ & $0.906^{* * *}$ & $0.495^{* *}$ & $0.834^{* * *}$ & $0.9499^{* * *}$ & $0.591 * *$ \\
& $(0.236)$ & $(0.297)$ & $(0.224)$ & $(0.240)$ & $(0.291)$ & $(0.234)$ \\
CORR.I & $0.098^{* * *}$ & $0.101^{* * *}$ & $0.092^{* * *}$ & $0.119^{* * *}$ & $0.115^{* * *}$ & $0.124^{* * *}$ \\
& $(0.035)$ & $(0.034)$ & $(0.033)$ & $(0.035)$ & $(0.037)$ & $(0.036)$ \\
FIN.D.CORR.I & $-0.306^{* * *}$ & $-0.353^{* * *}$ & $-0.193^{*}$ & $-0.393^{* * *}$ & $-0.431^{* * *}$ & $-0.318^{* *}$ \\
& $(0.101)$ & $(0.128)$ & $(0.100)$ & $(0.117)$ & $(0.142)$ & $(0.125)$ \\
& & & & & \\
\hline IV & & & & FIN80 & Legal Orig. \\
Obs. & 1189 & 1013 & 1189 & 1105 & 992 & 1105 \\
\hline \hline
\end{tabular}

Note: Dependent variables are real GDP/capita growth over 1980-2000 in Panels A\&B and growth rate of industry value added over 1980-1989 in Panel C. Stock_Traded is the ratio of the value of shares traded on the stock market to GDP; see section 5.2. Heteroskedasticity-robust standard errors in parentheses. Coefficients significant at 1\%,5\%, and $10 \%$ levels are denoted by ${ }^{* * *},{ }^{* *}$, and ${ }^{*}$, respectively. $\mathrm{D}=$ industry-level financial dependence. I = industry-level investment intensity. The instruments for FIN are its 1980 level, FIN80, in columns $2 \& 5$ and legal origin in columns $3 \& 6$. See note to Table 7 for information on unreported regressors and corruption variable averages. 
TABLE 12 - Cross-Country and Industry Analysis using Stock_Traded+Private_Credit

\begin{tabular}{|c|c|c|c|c|c|c|}
\hline & \multicolumn{3}{|c|}{$\begin{array}{c}\text { FIN = Stock_Traded+Private_Credit } \\
\text { CORR }=\text { Corruption_ICRG }\end{array}$} & \multicolumn{3}{|c|}{$\begin{array}{c}\text { FIN = Stock_Traded+Private_Credit } \\
\text { CORR }=\text { Corruption_TI }\end{array}$} \\
\hline & OLS & 2SLS(1) & $2 \mathrm{SLS}(2)$ & & $2 \mathrm{SLS}(1)$ & 2SLS $(2)$ \\
\hline & \multicolumn{6}{|c|}{ Panel A: Country-Level Regressions with Baseline Controls (1980-2000) } \\
\hline \multirow[t]{2}{*}{ FIN } & $0.072^{* * *}$ & $0.044^{* *}$ & $0.089 * * *$ & $0.069 * * *$ & 0.018 & $0.078 * * *$ \\
\hline & $(0.016)$ & $(0.022)$ & $(0.015)$ & $(0.009)$ & $(0.028)$ & $(0.012)$ \\
\hline \multirow[t]{2}{*}{ CORR } & $0.008^{* * *}$ & $0.006^{*}$ & $0.011^{* * *}$ & $0.009^{* * *}$ & 0.004 & $0.010 * * *$ \\
\hline & $(0.003)$ & $(0.004)$ & $(0.003)$ & $(0.003)$ & $(0.004)$ & $(0.003)$ \\
\hline \multirow[t]{3}{*}{ FIN.CORR } & $-0.013 * * *$ & $-0.008^{*}$ & $-0.016^{* * *}$ & $-0.014 * * *$ & -0.003 & $-0.016^{* * *}$ \\
\hline & $(0.003)$ & $(0.004)$ & $(0.003)$ & $(0.002)$ & $(0.006)$ & $(0.002)$ \\
\hline & \multicolumn{6}{|c|}{ Panel B: Country-Level Regressions with Extended Controls (1980-2000) } \\
\hline \multirow[t]{2}{*}{ FIN } & $0.073^{* * *}$ & $0.048 * *$ & $0.089^{* * *}$ & $0.066^{* * *}$ & 0.023 & $0.071^{* * *}$ \\
\hline & $(0.012)$ & $(0.021)$ & $(0.012)$ & $(0.009)$ & $(0.025)$ & $(0.012)$ \\
\hline \multirow[t]{2}{*}{ CORR } & $0.008^{* * *}$ & $0.006 *$ & $0.009 * * *$ & $0.007 * * *$ & 0.002 & $0.008 * * *$ \\
\hline & $(0.002)$ & $(0.003)$ & $(0.002)$ & $(0.003)$ & $(0.004)$ & $(0.003)$ \\
\hline \multirow[t]{2}{*}{ FIN.CORR } & $-0.014 * * *$ & $-0.009 * *$ & $-0.016^{* * *}$ & $-0.014^{* * *}$ & -0.005 & $-0.015^{* * *}$ \\
\hline & $(0.002)$ & $(0.004)$ & $(0.002)$ & $(0.002)$ & $(0.005)$ & $(0.002)$ \\
\hline IV & & FIN80 & Legal Orig. & & FIN80 & Legal Orig. \\
\hline \multirow[t]{2}{*}{ Obs. } & 80 & 73 & 80 & 62 & 56 & 62 \\
\hline & \multicolumn{6}{|c|}{ Panel C: Industry-Level Regressions } \\
\hline FIN·D & $\begin{array}{l}0.197 * * * \\
(0.069)\end{array}$ & $\begin{array}{l}0.207 * * * \\
(0.075)\end{array}$ & $\begin{array}{l}0.148 * * \\
(0.067)\end{array}$ & $\begin{array}{l}0.197 * * * \\
(0.068)\end{array}$ & $\begin{array}{l}0.202^{* * *} \\
(0.074)\end{array}$ & $\begin{array}{l}0.174 * * \\
(0.071)\end{array}$ \\
\hline $\mathrm{CORR} \cdot \mathrm{I}$ & $\begin{array}{l}0.115^{* * *} \\
(0.041)\end{array}$ & $\begin{array}{l}0.120^{* * *} \\
(0.043)\end{array}$ & $\begin{array}{l}0.110 * * \\
(0.045)\end{array}$ & $\begin{array}{l}0.137 * * * \\
(0.047)\end{array}$ & $\begin{array}{l}0.140 * * * \\
(0.048)\end{array}$ & $\begin{array}{l}0.143^{* * *} \\
(0.051)\end{array}$ \\
\hline FIN.D.CORR $\cdot \mathrm{I}$ & $\begin{array}{l}-0.073 * * \\
(0.029)\end{array}$ & $\begin{array}{l}-0.079 * * \\
(0.032)\end{array}$ & $\begin{array}{l}-0.058 * * \\
(0.029)\end{array}$ & $\begin{array}{l}-0.088 * * * \\
(0.033)\end{array}$ & $\begin{array}{l}-0.091 * * \\
(0.036)\end{array}$ & $\begin{array}{l}-0.085 * * \\
(0.036)\end{array}$ \\
\hline IV & & FIN80 & Legal Orig. & & FIN80 & Legal Orig. \\
\hline Obs. & 1111 & 1111 & 1111 & 1027 & 1027 & 1027 \\
\hline
\end{tabular}

Note: Dependent variables are real GDP/capita growth over 1980-2000 in Panels A\&B and growth rate of industry value added over 1980-1989 in Panel C. Stock_Traded is the ratio of the value of shares traded on the stock market to GDP; see section 5.2. Heteroskedasticity-robust standard errors in parentheses. Coefficients significant at $1 \%, 5 \%$, and $10 \%$ levels are denoted by ${ }^{* * *},{ }^{* *}$, and ${ }^{*}$, respectively. $\mathrm{D}=$ industry-level financial dependence. I = industry-level investment intensity. The instruments for FIN are its 1980 level, FIN80, in columns $2 \& 5$ and legal origin in columns $3 \& 6$. See note to Table 7 for information on unreported regressors and corruption variable averages. 
TABLE 13 - Cross-Country and Industry Analysis with Finance ${ }^{2}$

\begin{tabular}{lc|cc}
\hline \hline FIN $=$ Private_Credit & \multicolumn{2}{|c}{ FIN = Private_Credit } \\
CORR $=$ Corruption_ICRG & CORR = Corruption_TI \\
OLS & 2SLS $(1)$ & OLS & 2SLS $(1)$ \\
\hline \hline
\end{tabular}

Panel A: Country-Level Regressions with Baseline Controls

$\begin{array}{lllll}\text { FIN } & 0.134^{* * *} & 0.136^{* *} & 0.130^{* * *} & 0.108^{* *} \\ & (0.023) & (0.052) & (0.019) & (0.045) \\ \text { CORR } & 0.010^{* *} & 0.010^{* *} & 0.014^{* * *} & 0.007 \\ & (0.004) & (0.005) & (0.004) & (0.005) \\ \text { FIN.CORR } & -0.019^{* * *} & -0.018^{* *} & -0.024^{* * *} & -0.008 \\ & (0.005) & (0.008) & (0.006) & (0.010) \\ \text { FIN }^{2} & -0.012 & -0.024 & -0.003 & -0.043 \\ & (0.018) & (0.037) & (0.015) & (0.038)\end{array}$

Panel B: Country-Level Regressions with Extended Controls

\begin{tabular}{lllll} 
FIN & $0.122^{* * *}$ & $0.139^{* * *}$ & $0.120^{* * *}$ & $0.097^{* *}$ \\
& $(0.023)$ & $(0.045)$ & $(0.020)$ & $(0.047)$ \\
CORR & $0.011^{* * *}$ & $0.009^{* *}$ & $0.013^{* * *}$ & 0.006 \\
& $(0.003)$ & $(0.004)$ & $(0.004)$ & $(0.004)$ \\
FIN.CORR & $-0.022^{* * *}$ & $-0.017^{*}$ & $-0.023^{* * *}$ & -0.006 \\
& $(0.006)$ & $(0.009)$ & $(0.006)$ & $(0.010)$ \\
FIN $^{2}$ & 0.002 & -0.029 & -0.003 & -0.043 \\
& $(0.023)$ & $(0.035)$ & $(0.017)$ & $(0.039)$ \\
& & & \\
\hline IV & 71 & 56 & FIN60, FIN60 \\
Obs. & & 58 & 46 \\
\hline
\end{tabular}

Panel C: Industry-Level Regressions

\begin{tabular}{lllll} 
FIN.D & $0.296^{* * *}$ & $0.407^{* * *}$ & $0.258^{* *}$ & $0.406^{* * *}$ \\
& $(0.109)$ & $(0.135)$ & $(0.103)$ & $(0.135)$ \\
CORR.I & $0.095^{* *}$ & $0.096^{* *}$ & $0.121^{* *}$ & $0.112^{* *}$ \\
& $(0.043)$ & $(0.043)$ & $(0.050)$ & $(0.049)$ \\
FIN.D.CORR.I & $-0.070^{* *}$ & $-0.073^{* *}$ & $-0.081^{* *}$ & $-0.081^{* *}$ \\
& $(0.033)$ & $(0.035)$ & $(0.037)$ & $(0.039)$ \\
FIN $^{2} \cdot \mathrm{D}$ & -0.079 & $-0.156^{* *}$ & -0.058 & $-0.162^{* *}$ \\
& $(0.050)$ & $(0.060)$ & $(0.053)$ & $(0.066)$ \\
& & & & \\
\hline IV & & FIN80, FIN $80^{2}$ & & FIN80, FIN80 \\
Obs. & 11111099 & 1027 \\
\hline \hline
\end{tabular}

Note: Dependent variables are real GDP/capita growth over 1960-2000 in Panels A\&B and growth rate of industry value added over 1980-1989 in Panel C. Heteroskedasticity-robust standard errors in parentheses. Coefficients significant at $1 \%, 5 \%$, and $10 \%$ levels are denoted by $* * *, * *$, and $*$, respectively. D = industrylevel financial dependence. I = industry-level investment intensity. Instruments for FIN are its 1960 level and its square, FIN60 and FIN60 ${ }^{2}$, in columns 2\&4 of Panels A and B and its 1980 level and its square, FIN80 and FIN $80^{2}$, in columns $2 \& 4$ of Panel C. See note to Table 7 for information on unreported regressors and corruption variable averages. 
TABLE 14 - Cross-Country and Industry Analysis with Corruption ${ }^{2}$

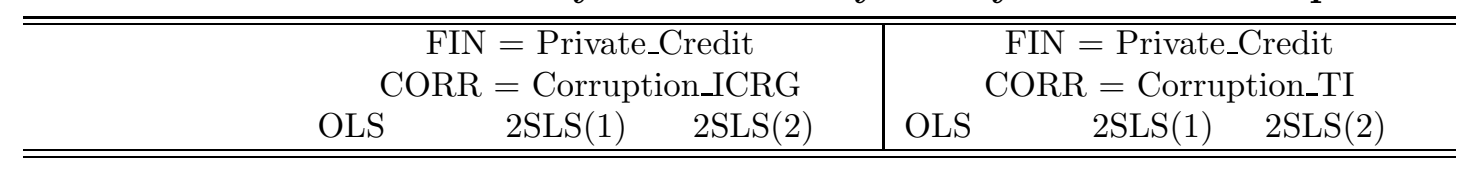

Panel A: Country-Level Regressions with Baseline Controls

$\begin{array}{lcclccc}\text { FIN } & 0.134^{* * *} & 0.119^{*} & 0.192^{* * *} & 0.139^{* * *} & 0.105^{* *} & 0.153^{* * *} \\ & (0.026) & (0.068) & (0.031) & (0.018) & (0.047) & (0.024) \\ \text { CORR } & 0.010 & 0.012 & 0.007 & 0.009 & 0.009 & 0.009 \\ & (0.007) & (0.009) & (0.007) & (0.006) & (0.007) & (0.006) \\ \text { FIN.CORR } & -0.022^{* * *} & -0.021 & -0.035^{* * *} & -0.027^{* * *} & -0.021^{*} & -0.029^{* * *} \\ & (0.005) & (0.013) & (0.006) & (0.004) & (0.010) & (0.005) \\ \text { CORR }^{2} & 0.000 & 0.000 & 0.001 & 0.001 & 0.001 & 0.001 \\ & (0.001) & (0.002) & (0.001) & (0.001) & (0.001) & (0.001)\end{array}$

Panel B: Country-Level Regressions with Extended Controls

\begin{tabular}{lccllll} 
FIN & $0.117^{* * *}$ & $0.136^{*}$ & $0.195^{* * *}$ & $0.127^{* * *}$ & $0.082^{*}$ & $0.144^{* * *}$ \\
& $(0.027)$ & $(0.068)$ & $(0.025)$ & $(0.018)$ & $(0.047)$ & $(0.020)$ \\
CORR & $0.013^{*}$ & 0.009 & 0.009 & 0.009 & 0.008 & 0.009 \\
& $(0.007)$ & $(0.010)$ & $(0.007)$ & $(0.006)$ & $(0.006)$ & $(0.006)$ \\
FIN.CORR & $-0.020^{* * *}$ & $-0.024^{*}$ & $-0.036^{* * *}$ & $-0.026^{* * *}$ & -0.016 & $-0.029^{* * *}$ \\
& $(0.005)$ & $(0.013)$ & $(0.005)$ & $(0.004)$ & $(0.011)$ & $(0.004)$ \\
CORR $^{2}$ & 0.000 & 0.000 & 0.001 & 0.001 & 0.000 & 0.001 \\
& $(0.001)$ & $(0.002)$ & $(0.001)$ & $(0.001)$ & $(0.001)$ & $(0.001)$ \\
& & & & & & \\
\hline IV & & FIN60 & Legal Orig. & & FIN60 & Legal Orig. \\
Obs. & & 56 & 71 & 58 & 46 & 58 \\
\hline
\end{tabular}

Panel C: Industry-Level Regressions

\begin{tabular}{lllllll} 
FIN.D & $0.205^{* * *}$ & $0.227^{* * *}$ & $0.191^{* *}$ & $0.124^{* *}$ & $0.141^{* *}$ & $0.148^{*}$ \\
& $(0.077)$ & $(0.085)$ & $(0.087)$ & $(0.057)$ & $(0.065)$ & $(0.083)$ \\
CORR·I & 0.201 & 0.178 & 0.209 & $0.421^{* *}$ & $0.404^{*}$ & $0.422^{* *}$ \\
& $(0.160)$ & $(0.165)$ & $(0.164)$ & $(0.200)$ & $(0.218)$ & $(0.213)$ \\
FIN.D.CORR·I & $-0.075^{* *}$ & $-0.085^{* *}$ & $-0.075^{* *}$ & $-0.058^{* *}$ & $-0.067^{* *}$ & $-0.077^{* *}$ \\
& $(0.032)$ & $(0.035)$ & $(0.037)$ & $(0.027)$ & $(0.030)$ & $(0.038)$ \\
CORR $^{2} \cdot \mathrm{I}$ & -0.012 & -0.007 & -0.012 & $-0.048^{*}$ & -0.044 & -0.045 \\
& $(0.017)$ & $(0.018)$ & $(0.018)$ & $(0.027)$ & $(0.030)$ & $(0.029)$ \\
& & & & & \\
\hline IV & 1183 & 1111 & 1183 & 1099 & 1027 & 1099 \\
Obs. & & & & & & \\
\hline \hline
\end{tabular}

Note: Dependent variables are real GDP/capita growth over 1960-2000 in Panels A\&B and growth rate of industry value added over 1980-1989 in Panel C. Heteroskedasticity-robust standard errors in parentheses. Coefficients significant at $1 \%, 5 \%$, and $10 \%$ levels are denoted by $* * *, * *$, and ${ }^{*}$, respectively. D = industrylevel financial dependence. I = industry-level investment intensity. Instruments for FIN are its 1960 level, FIN60, in columns 2\&5 of Panels A and B, its 1980 level, FIN80, in columns 2\&5 of Panel C, and legal origin in columns $3 \& 6$. See note to Table 7 for information on unreported regressors and corruption variable averages. 
TABLE 15 - Cross-Country and Industry Analysis with Finance-Initial_Level and Corruption-Initial_Level Interactions

\begin{tabular}{|c|c|c|c|c|c|c|}
\hline & \multicolumn{3}{|c|}{$\begin{array}{c}\text { FIN }=\text { Private_Credit } \\
\text { CORR }=\text { Corruption_ICRG }\end{array}$} & \multicolumn{3}{|c|}{$\begin{array}{c}\text { FIN }=\text { Private_Credit } \\
\text { CORR }=\text { Corruption_TI }\end{array}$} \\
\hline & OLS & 2SLS $(1)$ & $2 \mathrm{SLS}(2)$ & OLS & 2SLS(1) & $2 \mathrm{SLS}(2)$ \\
\hline & \multicolumn{6}{|c|}{ Panel A: Country-Level Regressions with Finance-Initial_GDP Interaction } \\
\hline \multirow[t]{2}{*}{ FIN } & $0.181^{* * *}$ & 0.217 & $0.227 * *$ & $0.175^{* * *}$ & 0.229 & $0.131^{*}$ \\
\hline & $(0.047)$ & $(0.144)$ & $(0.085)$ & $(0.041)$ & $(0.174)$ & $(0.071)$ \\
\hline \multirow[t]{2}{*}{ CORR } & $0.007^{*}$ & 0.007 & 0.004 & $0.012^{* *}$ & 0.003 & $0.017^{* * *}$ \\
\hline & $(0.004)$ & $(0.011)$ & $(0.008)$ & $(0.005)$ & $(0.015)$ & $(0.006)$ \\
\hline \multirow[t]{2}{*}{ FIN·CORR } & -0.010 & -0.008 & 0.000 & $-0.017 *$ & 0.004 & $-0.031 *$ \\
\hline & $(0.008)$ & $(0.028)$ & $(0.021)$ & $(0.010)$ & $(0.036)$ & $(0.016)$ \\
\hline \multirow[t]{3}{*}{ FIN·LGDP60 } & -0.012 & -0.017 & -0.021 & -0.009 & -0.025 & 0.003 \\
\hline & $(0.009)$ & $(0.030)$ & $(0.018)$ & $(0.009)$ & $(0.036)$ & $(0.015)$ \\
\hline & \multicolumn{6}{|c|}{ Panel B: Country-Level Regressions with Corruption-Initial_GDP Interaction } \\
\hline FIN & $0.141^{* * *}$ & $0.111^{*}$ & $0.197^{* * *}$ & $0.123^{* * *}$ & 0.063 & $0.136^{* * *}$ \\
\hline \multirow{2}{*}{ CORR } & 0.006 & 0.015 & 0.001 & $0.019 *$ & 0.021 & $0.019 *$ \\
\hline & $(0.010)$ & $(0.015)$ & $(0.011)$ & $(0.011)$ & $(0.013)$ & $(0.011)$ \\
\hline \multirow[t]{2}{*}{ FIN.CORR } & $-0.024^{* * *}$ & -0.019 & $-0.037^{* * *}$ & $-0.023^{* * *}$ & -0.010 & $-0.026^{* * *}$ \\
\hline & $(0.005)$ & $(0.012)$ & $(0.008)$ & $(0.005)$ & $(0.010)$ & $(0.007)$ \\
\hline \multirow[t]{2}{*}{ CORR.LGDP60 } & 0.001 & 0.000 & 0.002 & -0.001 & -0.001 & -0.001 \\
\hline & $(0.001)$ & $(0.002)$ & $(0.001)$ & $(0.001)$ & $(0.002)$ & $(0.001)$ \\
\hline IV & & FIN60 & Legal Orig. & & FIN60 & Legal Orig. \\
\hline Obs. & 71 & 56 & 71 & 58 & 46 & 58 \\
\hline
\end{tabular}

Note: Dependent variable is real GDP/capita growth over 1960-2000. Heteroskedasticity-robust standard errors in parentheses. Coefficients significant at 1\%, 5\%, and $10 \%$ levels are denoted by ***, **, and *, respectively. $\mathrm{LGDP} 60=\log$ real GDP/capita in 1960. Regressors included but not reported are $\log$ real GDP per capita in 1960 and log average school attainment in 1960. Corruption_ICRG is averaged over 1984-2000. Corruption_TI is averaged over 1980-2000. Instruments for FIN are its 1960 level, FIN60, in columns $2 \& 5$ and legal origin in columns $3 \& 6$. 
TABLE 16 - Cross-Country and Industry Analysis without Interaction Term

\begin{tabular}{ccc|ccc}
\hline \hline \multicolumn{2}{c|}{ FIN = Private_Credit } & \multicolumn{3}{c}{ FIN = Private_Credit } \\
\multicolumn{2}{c|}{ CORR = Corruption_ICRG } & \multicolumn{2}{c}{ CORR = Corruption_TI } \\
OLS & 2SLS $(1)$ & 2SLS $(2)$ & OLS & 2SLS $(1)$ & 2SLS $(2)$ \\
\hline \hline
\end{tabular}

Panel A: Country-Level Regressions with Baseline Controls

$\begin{array}{lcccccc}\text { FIN } & 0.034^{* * *} & 0.015 & 0.032 & 0.029^{* * *} & 0.015 & 0.031 \\ & (0.010) & (0.014) & (0.021) & (0.007) & (0.014) & (0.022) \\ \text { CORR } & 0.003 & 0.006^{* * *} & 0.004 & 0.005^{*} & 0.006^{* *} & 0.005 \\ & (0.002) & (0.002) & (0.002) & (0.003) & (0.003) & (0.003)\end{array}$

Panel B: Country-Level Regressions with Extended Controls

\begin{tabular}{lcclclc} 
FIN & $0.026^{* * *}$ & 0.015 & 0.033 & $0.021^{* * *}$ & 0.011 & 0.029 \\
& $(0.009)$ & $(0.013)$ & $(0.020)$ & $(0.007)$ & $(0.011)$ & $(0.021)$ \\
CORR & $0.004^{*}$ & $0.003^{*}$ & 0.003 & 0.004 & 0.003 & $0.003^{* * *}$ \\
& $(0.002)$ & $(0.002)$ & $(0.002)$ & $(0.003)$ & $(0.002)$ & $(0.003)$ \\
& & & & & \\
\hline IV & 71 & 56 & 71 & 58 & 46 & 58 \\
Obs. & 71 & FIN60 & Legal Orig. & & LIN60 \\
\hline
\end{tabular}

Panel C: Industry-Level Regressions

\begin{tabular}{lccllll} 
FIN.D & $0.049^{* *}$ & $0.044^{* *}$ & $0.056^{*}$ & 0.025 & 0.024 & 0.031 \\
& $(0.022)$ & $(0.021)$ & $(0.033)$ & $(0.020)$ & $(0.020)$ & $(0.033)$ \\
CORR.I & $0.048^{*}$ & $0.055^{*}$ & 0.046 & $0.074^{* *}$ & $0.078^{* * *}$ & $0.072^{* *}$ \\
& $(0.029)$ & $(0.029)$ & $(0.028)$ & $(0.030)$ & $(0.029)$ & $(0.031)$ \\
& & & & & \\
\hline IV & & FIN80 & Legal Orig. & & FIN80 & Legal Orig. \\
Obs. & 1183 & 1111 & 1183 & 1099 & 1027 & 1099 \\
\hline \hline
\end{tabular}

Note: Dependent variables are real GDP/capita growth over 1960-2000 in Panels A\&B and growth rate of industry value added over 1980-1989 in Panel C. Heteroskedasticity-robust standard errors in parentheses. Coefficients significant at $1 \%, 5 \%$, and $10 \%$ levels are denoted by ${ }^{* * *},{ }^{* *}$, and ${ }^{*}$, respectively. $\mathrm{D}=$ industrylevel financial dependence. I = industry-level investment intensity. Instruments for FIN are its 1960 level, FIN60, in columns 2\&5 of Panels A and B, its 1980 level, FIN80, in columns 2\&5 of Panel C, and legal origin in columns $3 \& 6$. See note to Table 7 for information on unreported regressors and corruption variable averages. 